\title{
Aleksander Smoliński Elementy tradycji byłego (Uniwersytet Mikołaja Kopernika) Wielkiego Księstwa Litewskiego w piechocie Wojska Polskiego Drugiej Rzeczypospolitej
}

\begin{abstract}
Każdy nowoczesny naród europejski w toku swojego historycznego, - wielowiekowego rozwoju wytworzył cały szereg elementów zbiorowej świadomości społecznej określanych wspólnym mianem tradycji. W najogólniejszym, współczesnym rozumieniu pojęcie to oznacza: „przekazywanie z pokolenia na pokolenie obyczajów, przekonań, zasad, [...] sposobów myślenia, odczuwania [...], postępowania, wydarzeń z przeszłości traktowanych jako hist. [oryczne - przyp. A. S.] (choć niesprawdzalnych), [...] przekazywany przez przodków obyczaj, wierzenie, zasada, itd." Jest to więc pewien niezwykle istotny element świadomości zbiorowej, która powinna cechować zarówno społeczeństwo, jak i wojsko, które mu służy. Ponadto musi tutaj zadziałać swoiste sprzężenie zwrotne, czyli wzajemne przenikanie się oraz oddziaływanie tradycji cywilnej i wojskowej. Zjawisko to dotyczyło, i w wielu wypadkach nadal dotyczy, również armii poszczególnych państw, przy czym jeszcze do niedawna na kontynencie europejskim tradycje wojskowe należały do jednych z ważniejszych, co powodowało, że były one troskliwie kultywowane.
\end{abstract}

${ }^{1}$ W. Kopaliński, Stownik wyrazów obcych i zwrotów obcojęzycznych, wyd. 18, Warszawa 1989, s. 518. Wcześniejszą definicję tego pojęcia, zgodną z tym, co rozumiano przez nie w okresie międzywojennym, podaje choćby: Wielka ilustrowana encyklopedia powszechna, t. 17: Szkocka literatura - Victor, Kraków [b.r.w.], s. 185. 
W okresie Drugiej Rzeczypospolitej podobnie było także w Wojsku Polskim, gdyż w powszechnym odbiorze społecznym siły zbrojne stanowiły wtenczas jeden z podstawowych wyznaczników całkowitej suwerenności narodu oraz jego państwa ${ }^{2}$. Sytuacja taka umożliwiała natomiast pełny i nieskrępowany rozkwit tradycji wojskowej.

Jednym z elementów wielowątkowej tradycji funkcjonującej w polskich siłach zbrojnych przed 1939 rokiem był etos dawnej Rzeczypospolitej Obojga Narodów, a co za tym idzie - pamięć o związkach Korony z byłym Wielkim Księstwem Litewskim. Ponadto w pewnych okresach budowanie w wojsku świadomości tradycji tego typu było zbieżne z oficjalną polityką ówczesnych polskich elit politycznych. Tak było choćby u progu niepodległości, kiedy to bezskutecznie próbowano realizować tak zwany program federacyjny ${ }^{3}$.

Wydaje się też, że o powstaniu w Drugiej Rzeczypospolitej takiej sytuacji zadecydowały przede wszystkim trzy czynniki. Pierwszym z nich był fakt, iż nie tylko w kręgach politycznych, ale również wśród elit intelektualnych i kulturalnych praktycznie przez cały okres międzywojenny istniała

${ }^{2}$ Zob. chociażby: A. S. Tomaszewski, Własna ścieżka przez życie. (Fragmenty wspomnień 1913-1970), Kraków 1978; F. Kusiak, Życie codzienne oficerów Drugiej Rzeczypospolitej, Warszawa 1992; J. Odziemkowski, Armia i spoleczeństwo II Rzeczypospolitej, Warszawa 1996; G. Jaskulski, Życie codzienne w garnizonie bydgoskim w latach 1920-1939, „Kronika Bydgoska”, 1998, t. 20; W. Sroczyński, Życie codzienne w 4 Kujawskim Pułku Artylerii Lekkiej w okresie międzywojennym, „Ziemia Kujawska”, 2000-2001, t. 14; J. J. Piątek, Żolnierz obywatel, „Kronika Miasta Poznania” (Za mundurem...), 2005, nr 1; J. Majka, Garnizon Rzeszów w latach 1918-1939, Rzeszów 2005; P. Borek, Garnizon Wojska Polskiego w Białej Podlaskiej w latach 1918-1939, Biała Podlaska 2006.

${ }^{3}$ Szerzej na ten temat zob.: J. Pajewski, Odbudowa państwa polskiego 1914-1918, Poznań 2005 (wyd. 1 - Warszawa 1978); idem, Budowa Drugiej Rzeczypospolitej 1918-1926, Kraków 1995; J. Cisek, Kilka uwag o myśli federacyjnej Józefa Pitsudskiego, [in:] Międzymorze. Polska i kraje Europy Środkowo-Wschodniej XIX-XX wiek, red. A. Ajnenkiel i in., Warszawa 1995; A. Czubiński, Walka o granice wschodnie Polski w latach 1918-1921, Opole 1993; idem, Walka Józefa Pitsudskiego o nowy kształt polityczny Europy Środkowo-Wschodniej w latach 1918-1921, Toruń 2002; P. Hauser, Federacyjna wizja Rzeczypospolitej w pogladach Józefa Pitsudskiego i próba jej urzeczywistnienia w latach 1918-1921, [in:] Polska i Ukraina. Sojusz 1920 roku i jego następstwa, red. Z. Karpus, W. Rezmer, E. Wiszka, Toruń 1997; J. GierowskaKałłaur, Ścieranie się koncepcji federacyjnej i inkorporacyjnej w stosunku do ziem bytego Wielkiego Księstwa Litewskiego w okresie poprzedzajacym Odezwę Wileńska, „Zeszyt Naukowy Muzeum Wojska", (Białystok) 2004, nr 17, a także częściowo już dzisiaj przestarzałe prace, jak: J. Lewandowski, Federalizm. Litwa i Białoruś w polityce obozu belwederskiego (XI 1918-IV 1920), Warszawa 1962; A. Deruga, Polityka wschodnia Polski wobec ziem Litwy, Białorusi i Ukrainy (1918-1919), Warszawa 1969. 
świadomość dawnej i długotrwałej wspólnoty państwowej Polaków i Litwinów. Poza tym czas ten, z perspektywy polskiej historii, był postrzegany bardzo korzystnie i wspominany z pewnym sentymentem, a nawet do pewnego stopnia idealizowany i gloryfikowany ${ }^{4}$. Stosunkowo świeżym zjawiskiem była też wówczas emancypacja narodowa i państwowa Litwinów, co powodowało, że, przynajmniej początkowo, liczono na możliwość znacznej poprawy wzajemnych polsko-litewskich relacji ${ }^{5}$. Ponieważ z reguły w rachubach tych nie uwzględniano jednak realnych stosunków, jakie panowały wtenczas na Litwie, plany te praktycznie aż do końca istnienia Drugiej Rzeczypospolitej okazały się niemożliwe do zrealizowania.

Kolejnym elementem było to, że w efekcie zbrojnego konfliktu polsko-litewskiego oraz powstania Litwy Środkowej, inkorporowanej w 1922 roku do Rzeczypospolitej Polskiej, w skład państwa polskiego weszły również ziemie, które kiedyś stanowiły integralną część historycznego Wielkiego Księstwa Litewskiego, by wspomnieć tutaj choćby Wileńszczyznę, która była jednym z najważniejszych elementów polsko-litewskiego sporu sprzed $1939 \mathrm{roku}^{6}$.

Na fakt obecności Rzeczypospolitej Obojga Narodów w świadomości przynajmniej części polskiego społeczeństwa wpływała także celowa polityka państwa oraz wojska. Pierwsze realizowało ją głównie poprzez szeroko rozumiany system oświatowy, a drugie przede wszystkim poprzez podejmowane wobec poborowych działania wychowawcze i oświatowe. Wojsko uważano bowiem wtenczas za bardzo ważny element mogący służyć integracji mocno zróżnicowanego społeczeństwa ówczesnej Rzeczypospolitej Polskiej. W związku z tym procesowi temu podlegali zarówno poborowi narodowości polskiej, jak i pochodzący z mniejszości

${ }^{4}$ Zob. W. Meysztowicz, Poszło z dymem. Gawędy o czasach i ludziach, Warszawa 1989; idem, Gawędy o czasach i ludziach, Londyn 1993; S. Mianowski, Świat, który odszedt. Wspomnienia Wilnianina 1895-1945, Warszawa 1995; E. Romer, Dziennik, t. 1: 1914-1918, t. 2: 1919-1923, Warszawa 1995; M. Jałowiecki, Na skraju imperium, Warszawa 2000; J. Kolbuszewski, Kresy, Wrocław 2002.

${ }_{5}$ Zob. choćby Kazimierz Świtalski. Diariusz 1919-1935, do druku przygotowali A. Garlicki, R. Świętek, Warszawa 1992.

${ }^{6}$ Szerzej zob.: J. Smoleński, Walki polsko-litewskie na Suwalszczyźnie we wrześniu 1920 r., Warszawa 1938; P. Łossowski, Stosunki polsko-litewskie 1918-1920, Warszawa 1966; idem, Konflikt polsko-litewski 1918-1920, Warszawa 1996; G. Łukomski, Wojna domowa. Zdziejów konfliktu polsko-litewskiego 1918-1920, Warszawa 1997; B. Kolarz, Ustrój Litwy Środkowej w latach 1920-1922, Gdańsk 2004. 
narodowych ${ }^{7}$, w tym również mniejszości litewskiej ${ }^{8}$. Próba rzetelnej oceny ewentualnej skuteczności tych działań, głównie w odniesieniu do żołnierzy Wojska Polskiego należących do różnych mniejszości narodowych i etnicznych, pomimo istnienia już obecnie pewnej literatury dotyczącej kwestii mniejszości w Wojsku Polskim ${ }^{9}$, wymaga jednak ze strony historyków polskich dalszych i pogłębionych badań źródłowych.

Jedną z metod, dzięki której w latach 1921-1939 w polskich siłach zbrojnych funkcjonował etos dawnej Rzeczypospolitej Obojga Narodów, było kultywowanie, obok rodzimych polskich, także wojskowych tradycji ziem wchodzących niegdyś w skład Wielkiego Księstwa Litewskiego. Oprócz

7 Szerzej na ten temat zob.: Centralne Archiwum Ministerstwa Spraw Wewnętrznych i Administracji, Sztab Generalny, teczka 66, Komunikat informacyjny „Obce narodowości w armii polskiej”, Oddział II Sztabu Generalnego Ministerstwa Spraw Wojskowych № 19737/ /II.Inf.F. z 18 X 1923 r.; K. Sochaniewicz, Jak prowadzić pogadanki z żotnierzami o dziejach ziemi, narodu i państwa polskiego, Sekcja Oświaty i Kultury Oddziału III Sztabu Ministerstwa Spraw Wojskowych, Warszawa 1920; Instrukcja szkolenia kawalerii, cz. 1: Organizacja i metody szkolenia, Departament Kawalerii Ministerstwa Spraw Wojskowych, Warszawa 1937; W. Tokarz, Znaczenie wychowawcze wojska, „Bellona”, 1918, z. 4; W. Brummer, Praca oświatowa w wojsku, „Bellona”, 1921, z. 1; Zbiór pytań i odpowiedzi opracowany przez grono oficerów 20 Pułku Piechoty Ziemi Krakowskiej, red. E. Jasiński, Kraków 1931; E. Jasiński, M. Słowikowski, Zbiór zasadniczych wiadomości wojskowych, Wilno 1934; P. Stawecki, Kilka uwag o roli wojska w procesach integracyjnych i dezintegracyjnych II Rzeczypospolitej, [in:] Drogi integracji społeczeństwa $w$ Polsce $w X I X-X X$ w., red. H. Zieliński, Wrocław-Warszawa-Kraków-Gdańsk 1976; idem, Polityka wojskowa Polski 1921-1926, Warszawa 1981; J. Odziemkowski, Armia i społeczeństwo II Rzeczypospolitej; T. A. Kowalski, Mniejszości narodowe w siłach zbrojnych Drugiej Rzeczypospolitej Polskiej (1918-1939), Torun 1997; W. Rezmer, Nauczanie przymusowe w Wojsku Polskim w okresie międzywojennym i jego rola w ksztaltowaniu propaństwowych postaw poborowych, [in:] Wychowanie a polityka. Tradycje $i$ współczesność, red. W. Wojdyło i M. Strzelecki, Torun 1997; idem, Problematyka narodowościowa i wyznaniowa w wojsku na terenie Dowództwa Okręgu Korpusu Nr VIII w Toruniu (1920-1939), [in:] Stosunki narodowościowe i wyznaniowe na Pomorzu w XIX i XX wieku, t. 6 : Mniejszości narodowe i wyznaniowe na Pomorzu w XIX i XX wieku, red. M. Wojciechowski, Toruń 1998; J. Kęsik, Naród pod broniq. Spoleczeństwo polskie w programie polskiej polityki wojskowej 1918-1939, Wrocław 1998.

${ }^{8}$ Zob. choćby: W. Rezmer, Litwini w Wojsku Polskim 1920-1939, [in:] Od armii komputowej do narodowej, t. 2: Dzieje militarne Polski i jej wschodnich sqsiadów od XVI do XX wieku, red. M. Krotofil i A. Smoliński, Torun 2005.

${ }^{9}$ Oprócz części wcześniej cytowanych prac zob. także: W. Rezmer, Mniejszości narodowe $i$ wyznaniowe w garnizonie toruńskim w latach 1920-1939, [in:] Stosunki narodowościowe $i$ wyznaniowe na Pomorzu w XIX i XX wieku, t. 3: Mniejszości narodowe i wyznaniowe w Toruniu w XIXi XX wieku, red. M. Wojciechowski, Toruń 1993; Mniejszości narodowe i wyznaniowe w siłach zbrojnych Drugiej Rzeczypospolitej 1918-1939, red. Z. Karpus, W. Rezmer, Toruń 2001. 
wykorzystywanych w toku szkolenia poborowych pewnych związanych z tym i jednocześnie zalecanych przez naczelne władze wojskowe treści wychowawczych, istotnymi składnikami tej tradycji były również nazwy i szefostwa ${ }^{10}$ oddziałów Wojska Polskiego oraz elementy symboliki oddziałowej, jak choćby weksylia ${ }^{11}$ czy też odznaki pamiątkowe. W najliczniejszej broni Wojska Polskiego, a mianowicie w piechocie ${ }^{12}$, do dziejów Wielkiego Księstwa Litewskiego nawiązywały wymienione poniżej formacje.

Pierwszą z nich był 76. Lidzki Pułk Piechoty imienia Ludwika Narbutta. Jego początkowe dzieje były związane z Samoobroną Wileńską, która stanowiła część zorganizowanej w końcu 1918 roku przez Polaków zamieszkałych na obszarze byłego Wielkiego Księstwa Litewskiego i skiero-

${ }^{10}$ Poza piechotą był to także 26. Pułk Ułanów imienia Hetmana Jana Karola Chodkiewicza. Szerzej na temat genezy i funkcjonowania tego zjawiska w europejskiej i polskiej tradycji wojskowej zob.: P. A. Rost, Szefostwa honorowe i szefostwa polskich oddziatów kawalerii 1918-1939 r., [in:] Wojsko Polskie 1914-1922, t. 2, red. B. Polak, Koszalin 1986; A. Smoliński, Europejskie i polskie tradycje szefostw wojskowych XVI-XX wieku, cz. 1, „Pro Memoria. Pismo Miłośników Przeszłości”, 2004, nr 2 (11); cz. 2, ibidem, 2004, nr 3 (12); idem, Szef czy patron-tradycja i współczesność w Wojsku Polskim, [in:] Od armii komputowej do narodowej, t. 2.

${ }^{11}$ Od łacińskiego vexillum oznaczającego choragiew lub proporzec. Tutaj w znaczeniu każdego przedmiotu mającego postać zbliżoną do choragwi lub sztandaru i pełniącego podobną funkcję - zob. choćby: J. Ptak, Choragiew w komunikacji społecznej w Polsce piastowskiej i jagiellońskiej, Lublin 2002, s. 6. W przedwojennym Wojsku Polskim były to więc choragwie i sztandary (od 1937 r. już tylko sztandary) oraz proporce oddziałowe, płomienie do fanfar i pokrowce na kotły. W poniższym materiale będzie jednak mowa wyłącznie o sztandarach.

${ }_{12}$ W siłach zbrojnych Drugiej Rzeczypospolitej, po ich przejściu na stope pokojową, istniały 84 pułki piechoty (o numerach od „1” do „45” oraz od „48” do „86”) i sześć pułków strzelców podhalańskich (o numerach od „1” do „6”) oraz po 1926 r., poza piechotą Korpusu Ochrony Pogranicza, trzy bataliony strzelców i samodzielny Batalion Ciężkich Karabinów Maszynowych, a także Batalion Stołeczny. W latach 30., oprócz batalionów Obrony Narodowej, dołączyły do nich również dwa morskie bataliony strzelców. Nie było już jednak Batalionu Ciężkich Karabinów Maszynowych - zob. np.: H. Piątkowski, Zarys historii wojennej 1-go Batalionu Strzelców (b. Batalionu Szturmowego kapitana Maczka przy 1-ej Dywizji Jazdy), Warszawa 1931; S. Hartman, Zarys historii wojennej 3-go Batalionu Strzelców (b. Batalionu Manewrowego), Warszawa 1932; K. Z. Rybicki, Zarys historii wojennej 2-go batalionu Strzelców, Warszawa 1938; M. Cieplewicz, Wojsko Polskie w latach 1921-1939. Organizacja, wyposażenie, wyszkolenie, Wrocław-Warszawa-Kraków 1998; Zarys dziejów wojskowości polskiej w latach 1864-1939, red. P. Stawecki, Warszawa 1990; Z. Gnat-Wieteska, Batalion Stołeczny, „Przegląd Historyczno-Wojskowy”, 2004, R. 5 (56), nr 4 (204); P. Zarzycki, Batalion Stołeczny, Pruszków 2005; Z. Jagiełło, Piechota Wojska Polskiego 1918-1939, Warszawa 2005. 
wanej przeciw Sowietom oraz Niemcom Samoobrony Litwy i Białorusi ${ }^{13}$. Następnie oddział ten, jako Lidzki Pułk Strzelców ${ }^{14}$, znalazł się najpierw w 1.15, a potem w 2. Dywizji Litewsko-Białoruskiej ${ }^{16}$, w szeregach której walczył w wojnie polsko-sowieckiej. Jesienią 1920 roku wziął również czynny udział w operacjach wojsk Litwy Środkowej skierowanych przeciwko siłom zbrojnym Republiki Litewskiej ${ }^{17}$. Dnia 21 października 1922 r. przemianowano go na 76. Lidzki Pułk Piechoty ${ }^{18}$, a w marcu 1938 r., choć wcześniej oddział prosił o miano 76. Lidzkiego Pułku Strzelców ${ }^{19}$, nada-

${ }^{13}$ Zob.: W. Wejtko, Samoobrona Litwy i Białorusi. Szkic historyczny, Wilno 1930; J. Dziczkaniec, Samoobrona Ziemi Lidzkiej, Lida 1938; K. Filipow, Samoobrona Ziemi Lidzkiej 1918/1919 r., „Zeszyt Naukowy Muzeum Wojska”, 1991, z. 5; M. Wrzosek, Wojny o granice Polski Odrodzonej 1918-1921, Warszawa 1992.

${ }^{14}$ Od 6 IV 1919 r.

15 Początkowo dywizja ta nie miała numeru i była nazywana jedynie Dywizją Litewsko-Białoruską. Z biegiem czasu zaczęto jednak używać także numeru „1”, który od października 1919 r. stał się integralną częścią jej nazwy - zob. choćby: Centralne Archiwum Wojskowe (dalej: CAW), Generalny Inspektorat Artylerii, sygn. 300.26.10, Rozkaz nr 47 Sztabu Generalnego WP nr dz. 01535 z 9 XII 1918 r.; S. Szeptycki, Front Litewsko-Białoruski. 10 marca 1919-30 lipca 1920, Kraków 1925.

${ }^{16}$ Dnia 21 X 1919 r. dokonano podziału dotychczasowej Dywizji Litewsko-Białoruskiej. Powstała wtenczas 1. Dywizja Litewsko-Białoruska (późniejsza 19. Dywizja Piechoty) objęła Wileński, Miński (I Brygada), Grodzieński oraz Nowogródzki (II Brygada) Pułki Strzelców. Natomiast w skład 2. Dywizji Litewsko-Białoruskiej (potem 20. Dywizji Piechoty, której pułki ostatecznie znalazły się w pokojowych 20. i 29. Dywizjach Piechoty) weszły Lidzki, Kowieński (III Brygada), Białostocki oraz Słucki (IV Brygada) Pułki Strzelców-zob.: CAW, NDWP Oddział I, sygn. 301.7.23, Meldunek gen. porucznika Stanisława Szeptyckiego dowódcy Frontu Litewsko-Białoruskiego L. 6601/I z 26 VIII 1919 r.; ibidem, Rozkaz Oddziału I NDWP 1. dz. 3868/I z 21 X 1919 r.; J. Majchrzakówna, Dowództwa Dywizji Piechoty, [in:] Spis władz wojskowych, Archiwum Wojskowe, Warszawa 1935, maszynopis w zbiorach CAW; Księga chwaty piechoty, przewodniczaccy komitetu redakcyjnego B. Prugar-Ketling, Warszawa 1937-1939, s. 202-203, 231-233.

${ }^{17} \mathrm{Na}$ Litwę Środkową pułk dotarł jednak dopiero w drugiej połowie października $1920 \mathrm{r}$. Szerzej na temat dziejów tej formacji zob. Zarys historii wojennej 76-go Lidzkiego Pułku Piechoty, z polecenia Wojskowego Biura Historycznego opracowała komisja pułkowa, Warszawa 1930.

${ }^{18}$ Według autorów Spisu byłych oddziałów Wojska Polskiego (Archiwum Wojskowe, Warszawa 1935, maszynopis w zbiorach CAW) oddział przemianowano wówczas na 76. Pułk Piechoty, z pominięciem „Lidzki”. Zob. także: Spis byłych oddziałów Wojska Polskiego, „Przegląd Historyczno-Wojskowy”, 2000, R. 1 (52), nr 2 (183), s. 96.

${ }^{19}$ W 1928 r. szef ówczesnego Wojskowego Biura Historycznego gen. brygady Julian Stachiewicz, oceniając propozycje nazw dla 76., 77. i 78. Pułków Piechoty, napisał: „Pułki 76-y, 77-y i 78-y [...] wiążą swą tradycję z oddziałami samoobrony na Kresach. Weszły one w skład 2-ej Dywizji Litewsko-Białoruskiej. Nazwy podane przeze mnie były używane 
no mu jego ostateczną, związaną z szefostwem, nazwę ${ }^{20}$. Jego pokojowym garnizonem było Grodno ${ }^{21}$.

Poza kultywowaniem tradycji odnoszących się do okresu walk „o niepodległość i granice” w latach 1918-1921, w symbolice oddziałowej pułk nawiązywał również do swego „litewskiego” rodowodu. Jednym z takich elementów była nowa, druga $\mathrm{z}$ kolei ${ }^{22}$, odznaka pułkowa zatwierdzona przez ministra spraw wojskowych 14 maja $1938 \mathrm{roku}^{23}$. Miała ona postać krzyża łacińskiego o wymiarach $43 \times 31 \mathrm{~mm}$, o ramionach zakończonych kulkami. Na krzyż nałożono dwupolowy herb Rzeczypospolitej Obojga Narodów z Orłem i Pogonią, zwieńczony stylizowaną koroną jagiellońską oraz datą „1863”. Herb został ujęty koroną cierniową, która w okresie powstania styczniowego była często używanym symbolem narodu cier-

w czasie wojny od chwili powstania pułków [...]. Poza tym zmieniłem nieco nazwy, o jakie pułki proszą, zachowując ich treść zasadniczą". W przypadku tego oddziału generał proponował, aby otrzymała ona postać: 76. Pułk Strzelców Lidzkich - zob.: CAW, Wojskowe Biuro Historyczne, sygn. 341.1.52, Pismo szefa Wojskowego Biura Historycznego do szefa Biura Ogólnoorganizacyjnego MSWojsk. z 30 VI 1928 r.

${ }^{20}$ Dziennik Rozkazów MSWojsk. nr 2 z 4 III 1938 r., poz. 26; A. Smoliński, Szef czy patron-tradycja i wspótczesność w Wojsku Polskim, s. 521-522.

${ }^{21}$ Znajdując się w składzie wojsk Litwy Środkowej oraz w pierwszym okresie po jej inkorporacji do Rzeczypospolitej Polskiej pułk stacjonował w miejscowości Bieniakonie - zob.: CAW, Oddział II Sztabu Głównego, sygn. 303.4.92, Komunikat dyslokacyjny z wyszczególnieniem obecnych oraz już zarządzonych zmian miejsc postoju formacji wojskowych wszystkich rodzajów broni-Oddział I Sztabu Generalnego MSWojsk. L. 6607/O.D.B. z 9 VI 1922 r.; ibidem, sygn. 302.4.139, Komunikat dyslokacyjny sił zbrojnych - Biuro Ogólnoorganizacyjne MSWojsk. L. 1150/Org. z 15 IX 1929 r.; CAW, Dowództwo Okręgu Korpusu VIII, sygn. 371.8.87, Komunikat dyslokacyjny dowództw dywizji piechoty, dywizji i brygad kawalerii oraz formacji ewidencyjnych wszystkich rodzajów broni - Biuro Ogólnoorganizacyjne MSWojsk. L. 3088/Org. z 21 IX 1926 r.

22 Pierwsza odznaka pamiątkowa została zatwierdzona przez ministra spraw wojskowych 12 IV 1922 r. - zob.: Dziennik Rozkazów MSWojsk. nr 16 z 18 V 1929 r., poz. 159. Nie miała ona jednak żadnych elementów związanych z symboliką byłego Wielkiego Księstwa Litewskiego jako części dawnej Rzeczypospolitej Obojga Narodów, choć według większości badaczy znajdował się na niej ,stylizowany orzeł jagielloński”, określany też niekiedy jako „typu jagiellońskiego” - szerzej zob.: H. Wielecki, R. Sieradzki, Wojsko Polskie 1921-1939. Odznaki pamiatkowe piechoty, Warszawa 1991, s. 124-125; K. Filipow, B. Wróblewski rysunki, Odznaki pamiatkowe Wojska Polskiego 1921-1939. Piechota, Warszawa 1995, s. 64; Z. Sawicki, A. Wielechowski, Odznaki Wojska Polskiego 1918-1945. Katalog zbioru falerystycznego. Wojsko Polskie 1918-1939. Polskie Sity Zbrojne na Zachodzie, Warszawa 2007, s. 122-123.

${ }^{23}$ Dziennik Rozkazów MSWojsk. nr 5 z 14 V 1938 r., poz. 51. 
piącego w niewoli ${ }^{24}$. Tło pól było szrafowane ${ }^{25}$. Na górnym ramieniu krzyża umieszczono nazwę leżącej na obszarze dawnego Wielkiego Księstwa Litewskiego miejscowości „DUBICZE”, w której 11 kwietnia 1863 roku została stoczona bitwa między Rosjanami a oddziałem powstańczym dowodzonym przez Ludwika Narbutta, poległego w tym starciu. Natomiast na dolnym ramieniu krzyża znalazł się monogram spleciony z inicjałów jego imienia i nazwiska - „LN” oraz data i napis „1919 WILNO”. Tę jednoczęściową odznakę wykonano w srebrze lub w tombaku w postaci surowego oksydowanego krzyża srebrnego o groszkowanej powierzchni i bez emaliii ${ }^{26}$.

Szczegółowego wyglądu sztandaru ${ }^{27}$ 76. Lidzkiego Pułku Piechoty, wręczonego oddziałowi 11 lutego 1923 roku w Grodnie, a obecnie znajdującego się w zbiorach Instytutu Polskiego i Muzeum imienia Generała Sikorskiego w Londynie, nie udało się autorowi ustalić ${ }^{28}$.

${ }^{24}$ Symbolika ta nawiązywała do biżuterii patriotycznej noszonej po 1861 r., głównie zaś w czasie oraz po upadku powstania styczniowego. Po raz kolejny podobne motywy w biżuterii tego typu oraz w różnorodnych oznakach i znaczkach pamiątkowych oraz okolicznościowych powróciły podczas pierwszej wojny światowej. Wtenczas dominował już jednak motyw dwu- lub trzypolowego herbu dawnej Rzeczypospolitej Obojga Narodów - zob. choćby: M. Szuman-Gorczyca, A. Żaczek - zdjęcia, Biżuteria patriotyczna. Katalog zbioru Muzeum Okręgowego w Koninie, Konin 1986; G. Kieniewiczowa, Pamiqtki powstań narodowych wzbiorach Muzeum Historycznego m.st. Warszawy, Warszawa 1988; M. Dubrowska, Pamiqtki I wojny światowej w Muzeum Historycznym m.st. Warszawy. Zbiór Krzysztofa Klingera, Warszawa 1994; W. Bigoszewska, Polska biżuteria patriotyczna, Warszawa 2003.

${ }^{25}$ Zabieg ten polegał na cieniowaniu rysunku, ryciny lub tła przedmiotu będącego wyrobem jubilerskim czy też grawerskim równoległymi albo krzyżującymi się liniami w celu ich skontrastowania z innymi powierzchniami gładkimi - zob. choćby Słownik terminologiczny sztuk pięknych, red. K. Kubalska-Sulkiewicz i in., Warszawa 2003, s. 403. Ponadto zob. także M. Gradowski, Dawne złotnictwo. Technika i terminologia, Warszawa 1980.

${ }^{26}$ Szerzej na temat tej odznaki zob.: H. Wielecki, R. Sieradzki, op. cit., s. 125; K. Filipow, B. Wróblewski - rysunki, op. cit., s. 64-65; Z. Sawicki, A. Wielechowski, op. cit., s. $123-124$.

27 Autor posługuje się tutaj terminologią obowiązującą dopiero od $1937 \mathrm{r}$. Do tego bowiem momentu weksylia tego typu używane w piechocie oficjalnie nazywano choragwiami. Sztandarami zaś określano jedynie znaki posiadane przez pułki kawalerii - zob.: Dziennik Ustaw RP nr 69 z 28 VIII 1919 r., poz. 416 - Ustawa z dnia 1 sierpnia 1919 r. o godłach i barwach Rzeczypospolitej Polskiej; ibidem, nr 5 z 28 I 1937 r., poz. 32 - Dekret Prezydenta Rzeczypospolitej z dnia 24 listopada 1937 r. o znakach wojska i marynarki wojennej.

${ }^{28}$ Rysunek zawarty w Księdze chwały piechoty... (metryka 76. Lidzkiego Pułku Piechoty) zdaje się sugerować, co jest mało prawdopodobne, że na odwrotnej stronie płatu tego ufundowanego przez Koło Polek z Lidy znaku nie było żadnych elementów związanych z miejscem pochodzenia pułku ani też świadczących o jego tradycji i wojennych dziejach. Ponadto 
Podobną historię miał również 77. Pułk Piechoty, który rozpoczynał swe dzieje jako Kowieński Pułk Strzelców ze składu 1. Dywizji Litewsko-Białoruskiej. W jej szeregach, a następnie w składzie 2. Dywizji Litewsko-Białoruskiej, walczył w wojnie polsko-sowieckiej. Ponadto od drugiej połowy października 1920 roku brał udział w walkach z wojskami litewskimi na terenie Litwy Środkowejej. Dnia 12 października 1921 roku przemianowano go na 77. Pułk Piechoty ${ }^{30}$. Jednak nieformalnie oddział posługiwał się również nazwą „77. Pułk Strzelców Kowieńskich” ${ }^{\text {”1 }}$. Miejscem jego stałego postoju była Lida ${ }^{32}$.

Elementy związane z etosem byłego Wielkiego Księstwa Litewskiego oraz z tradycją unii polsko-litewskiej znalazły się na pułkowej odznace pamiątkowej, zatwierdzonej przez ministra spraw wojskowych w lutym $1922 \mathrm{roku}^{33}$. Odznaka o wymiarach $41 \times 35,5 \mathrm{~mm}^{34}$ miała kształt emaliowanej na czerwono, trójkątnej tarczy o zaokrąglonych bokach i lekko łu-

zob. także: Zarys historii wojennej 76-go Lidzkiego Putku Piechoty, s. 43-44; K. Satora, Opowieści wrześniowych sztandarów, Warszawa 1990, s. 141-144.

${ }^{29}$ Szerzej na temat dziejów tej formacji zob.: Sz. Baron, Zarys historii wojennej 77-go Pułku Piechoty, Warszawa 1929; W. Markert, 77 Pułk Strzelców Kowieńskich, Pruszków 2002; idem, 77 Pułk Strzelców Kowieńskich w latach 1918-1939, Pruszków 2003.

${ }^{30}$ Tak podają autorzy Spisu byłych oddziałów Wojska Polskiego. Zob. także: Spis byłych oddziałów Wojska Polskiego, s. 96. W literaturze można natomiast napotkać informacje, że zmiana nazwy pułku nastąpiła już 22 VIII $1921 \mathrm{r}$.

31 Tak podaje W. Markert, 77 Pułk Strzelców Kowieńskich w latach 1918-1939, s. 74. W 1928 r. takie samo brzmienie nazwy pułku proponował szef Wojskowego Biura Historycznego gen. brygady Julian Stachiewicz - zob. CAW, Wojskowe Biuro Historyczne, sygn. 341.1.52, Pismo szefa Wojskowego Biura Historycznego do szefa Biura Ogólnoorganizacyjnego MSWojsk. z 30 VI 1928 r.

${ }^{32}$ Należąc do składu wojsk Litwy Środkowej oraz w pierwszym okresie po jej inkorporacji do Rzeczypospolitej Polskiej pułk stacjonował w Nowowilejce-zob.: CAW, Oddział II Sztabu Głównego, sygn. 303.4.92. Komunikat dyslokacyjny z wyszczególnieniem obecnych oraz już zarządzonych zmian miejsc postoju formacji wojskowych wszystkich rodzajów broni-Oddział I Sztabu Generalnego MSWojsk. L. 6607/O. de B. z9 VI 1922 r.; ibidem, sygn. 302.4.139, Komunikat dyslokacyjny sił zbrojnych - Biuro Ogólnoorganizacyjne MSWojsk. L. 1150/ /Org. z 15 IX 1929 r.; CAW, Dowództwo Okręgu Korpusu VIII, sygn. 371.8.87, Komunikat dyslokacyjny dowództw dywizji piechoty, dywizji i brygad kawalerii oraz formacji ewidencyjnych wszystkich rodzajów broni - Biuro Ogólnoorganizacyjne MSWojsk. L. 3088/Org. z 21 IX 1926 r.

${ }_{33}$ Dziennik Rozkazów MSWojsk. nr 9 z 28 II 1922 r., poz. 135. Zob. także ibidem, nr 4 z 30 I 1923 r., poz. 43.

${ }^{34}$ Odznaka mogła mieć również nieco odmienne wymiary, jak choćby $44 \times 35 \mathrm{~mm}$ lub $40 \times 33 \mathrm{~mm}$ oraz inne. 
kowatym szczycie, noszonej na srebrnym łańcuszku ${ }^{35}$, zaczepionym o wystające ponad górny brzeg tarczy złote rękojeści dwóch nałożonych na nią skrzyżowanych szabel. U góry tarczy umieszczono też polskiego Orła oraz litewską Pogoń, a u dołu stojącego niedźwiedzia - herb Żmudzi ${ }^{36}$. Ponadto pomiędzy tymi herbami wstawiono złożoną $\mathrm{z}$ dwóch części datę powstania pułku, a mianowicie: „12 XII” - „1918”. Wszystkie te elementy miały barwę srebrną. Brzeg tarczy był obwiedziony srebrną obwódką z gwoździami. Czteroczęściową odznakę oficerską, złoconą i emaliowana, bito w srebrze, a dwuczęściowa, pozbawioną emalii odznakę żołnierską wykonywano z tombaku oraz srebrzono i patynowano ${ }^{37}$.

W pułku tym przyjęła się także tradycja noszenia na naramiennikach kurtek i płaszczy oznaki w postaci stojącego niedźwiedzia z herbu Żmudzi, takiego samego jak na odznace pułkowej. W 1922 roku oznaka ta (zob. tablica 1) została formalnie zaakceptowana przez Ministerstwo Spraw Wojskowych $^{38}$. Jej powstanie i noszenie było związane $\mathrm{z}$ faktem pozostawania Kowna poza granicami odrodzonej Rzeczypospolitej Polskiej, co dla wielu Polaków wywodzących się z tych okolic było dużym ciosem. Skupili się oni wokół Tymczasowego Komitetu Politycznego Ziemi Kowieńskiej, którego zadaniem było utrzymywanie więzi z ziemianami polskimi pozostałymi po litewskiej stronie granicy oraz dokumentowanie udziału ludności tych ziem w walce o niepodległość państwa polskiego. Stąd też szczególną opieką otaczano 77. Pułk Piechoty. Nieudane starania o nagrodzenie sztan-

${ }^{35}$ Znane są też egzemplarze noszone w sposób klasyczny, a mianowicie na śrubce z nakrętką.

${ }^{36} \mathrm{~W}$ regulaminie odznaki pamiątkowej 77. Pułku Piechoty zamieszczonym w Rozkazie dziennym nr 85 dowództwa pułku z 23 III 1922 r., poz. 6, napisano: „Na tle amarantowej tarczy wizerunek Orła i Pogoni - symbol jedności Litwy z Polską; u dołu niedźwiadek (herb Żmudzi) symbol tej ziemi skąd powstała kadra 77 pp (dawniej Kowieńskiego Pułku Strzelców). Na tle tarczy dwie skrzyżowane szable ze złotymi gardami [czyli rękojeściami - przyp. A. S.] jako symbol gotowości pułku do podjęcia walki w obronie Ojczyzny i jej honoru" - cyt. za: W. Markert, 77 Pułk Strzelców Kowieńskich w latach 1918-1939, s. 79.

37 Szerzej na temat tej odznaki zob.: M. Wełna, Odznaczenia i odznaki jednostek Wojska Polskiego 1914/1918-1939/1945. Katalog wystawy zorganizowanej z okazji 70 rocznicy odzyskania Niepodległości, Wrocław 1988, s. 59 - poz. 348; H. Wielecki, R. Sieradzki, op. cit., s. 127; K. Filipow, B. Wróblewski - rysunki, op. cit., s. 65; Z. Sawicki, A. Wielechowski, op. cit., s. 124-125.

${ }^{38}$ Dziennik Rozkazów MSWojsk. nr 17 z 25 IV 1922 r., poz. 249, gdzie napisano: „Naczelnik Państwa i Wódz Naczelny decyzją z dnia 28 III 22. zezwolił na noszenie przez 77 p.p. na naramiennikach odznaki: »Niedźwiedzi«". Ponadto zob. także: ibidem, nr 22 z 4 VIII 1927 r., poz. 268, oraz nr 24 z 30 VII 1930 r., poz. 286. 
daru pułku Krzyżem Srebrnym Orderu Wojennego Virtuti Militari spowodowały, że powstała idea opracowania takiej oznaki, która wyróżniałaby pułk spośród innych oddziałów Wojska Polskiego. Ostatecznie narodził się pomysł zastąpienia noszonej dotychczas przez żołnierzy pułku numeracji porządkowej oznaką w postaci herbu Żmudzi i ziemi kowieńskiej. W wyniku podjętych wówczas działań 22 kwietnia 1922 roku członkowie Tymczasowego Komitetu Politycznego Ziemi Kowieńskiej podczas audiencji u Pierwszego Marszałka Polski Józefa Piłsudskiego dowiedzieli się, że złożony przez nich uprzednio $w$ tej sprawie wniosek uzyskał jego akceptację. Był to $\mathrm{z}$ jego strony wyraz uznania dla zasług bojowych żołnierzy 77. Pułku Piechoty, a jednocześnie podkreślenie odrębności tradycji tego oddziału. Szybko też opracowano wzór tej oznaki, zatwierdzony przez Ministerstwo Spraw Wojskowych w sierpniu tego roku - „Niedźwiadki dla oficerów haftowane nicią srebrną [bajorkiem - przyp. A. S.], jak gwiazdki - dla szeregowych blaszane, jak cyfry [numeracja porządkowa - przyp. A. S.] na naramiennikach" 39 .

Oznaka ta przedstawiała stojącego srebrnego niedźwiedzia o wielkości numeracji porządkowej noszonej w innych pułkach. Wkrótce po zatwierdzeniu pojawiła się na umundurowaniu i szybko stała się ważnym elementem tradycji oddziałowej 77. Pułku Piechoty. Spełniła też swoją funkcję, stając się istotnym czynnikiem wzmacniającym więź żołnierzy z pułkiem i wyróżniając ich spośród innych formacji do tego stopnia, że nazywano ich „niedźwiadkami” ${ }^{40}$. Jej wprowadzenie spowodowało, że 77. Pułk Piechoty w całym Wojsku Polskim był jedynym oddziałem noszącym na naramiennikach oznakę opartą na kształcie historycznego herbu ziemskiego.

Warto tutaj zauważyć, że część oznak noszonych w pułku była nieheraldyczna. Prawidłowo bowiem głowa niedźwiedzia powinna być skierowana w prawo. Tymczasem, zapewne z powodów estetycznych, na oznakach noszonych na prawych naramiennikach była ona zwrócona w lewo ${ }^{41}$.

39 Dziennik Rozkazów MSWojsk. nr 34 z 22 VIII 1922 r., poz. 493. Zob. także W. Markert, 77 Putk Strzelców Kowieńskich w latach 1918-1939, s. 84-85.

${ }^{40}$ W. Markert, 77 Pułk Strzelców Kowieńskich w latach 1918-1939, s. 85. Warto też tutaj dodać, że po 1933 r. w pułku przez pewien czas trzymano dwie żywe maskotki, a mianowicie niedźwiedzia Boya oraz niedźwiedzicę Baśkę - ibidem, s. 75.

${ }^{41}$ Fotografie takich oznak przytoczył W. Markert, 77 Pułk Strzelców Kowieńskich w latach 1918-1939, s. 82. 
Cztery stojące niedźwiedzie, jako element zaczerpnięty z herbu ziemi kowieńskiej, znalazły się również w rogach płatu sztandarowego ${ }^{42}$, pomiędzy ramionami krzyża kawalerskiego, na jego prawej (głównej) stronie ${ }^{43}$. Natomiast pierwotnie na stronie lewej (odwrotnej), w rogach między ramionami krzyża, umieszczono cztery monogramy „PSK” (Pułk Strzelców Kowieńskich). Ponadto do 1921 roku na stronie prawej tego ufundowanego w 1919 r. przez Tymczasowy Komitet Polityczny Ziemi Kowieńskiej sztandaru znajdował się też wizerunek Matki Boskiej Ostrobramskiej, zastąpiony następnie godłem państwowym. Wtenczas również monogramy „PSK” zastapiono numeracją porządkową w postaci liczby „77”44. Tak zmodyfikowany sztandar został wręczony pułkowi w Lidzie 18 kwietnia 1922 roku przez Naczelnika Państwa i Pierwszego Marszałka Polski Józefa Piłsudskiego $0^{45}$. Zmiana tych elementów miała związek z koniecznością dostosowania wyglądu sztandaru do oficjalnych przepisów obowiązujących wtenczas w Wojsku Polskim oraz z koniecznością ich zatwierdzania przez ministra spraw wojskowych ${ }^{46}$.

Kolejną formacją, której historia była związana najpierw z Samoobroną Litwy i Białorusi, a dokładniej z Samoobroną Ziemi Grodzieńskiej, a następnie z 1. Dywizją Litewsko-Białoruską, był późniejszy 81. Pułk Strzelców Grodzieńskich imienia Króla Stefana Batorego. Oddział ten powstał już w listopadzie 1918 roku jako 1. Pułk Strzelców Grodzieńskich, a 12 października $1921 \mathrm{r}^{47}$ został przemianowany na 81 . Pułk Strzelców

${ }^{42}$ Przy omawianiu weksyliów tego typu autor będzie starał się stosować terminologię oraz sposób ich opisu zaproponowany w pracy: J. Luczak, Choragwie weteranów Powstania Wielkopolskiego 1918-1919 w zbiorach Wielkopolskiego Muzeum Wojskowego, Poznań 1999. Ponadto zob. także M. Gradowski, Z. Żygulski jun., Słownik uzbrojenia historycznego, Warszawa 1998.

${ }_{43}$ Projektant oraz wykonawcy tego sztandaru pomylili jednak strony jego płatów, co spowodowało, że otrzymał on nieheraldyczny i jednocześnie niezgodny z oficjalnie obowiązującymi w tej kwestii przepisami kształt. Stąd też w rzeczywistości jego strona prawa była lewą i odwrotnie.

${ }^{44}$ Sz. Baron, op. cit., s. 28-29; W. Markert, 77 Pułk Strzelców Kowieńskich w latach $1918-1939$, s. $78,81$.

45 Sz. Baron, op. cit., s. 29.

${ }^{46}$ Zob.: Dziennik Ustaw RP nr 69 z 28 VIII 1919 r., poz. 416 - Ustawa z dnia 1 sierpnia 1919 r. o godłach i barwach Rzeczypospolitej Polskiej; S. Łoza, Z. Czaykowski - rysunki, Godło i barwy Rzeczypospolitej Polskiej, Zakłady Graficzne Ministerstwa Spraw Wojskowych, Warszawa 1921. Ponadto zob. także: Dziennik Rozkazów MSWojsk. nr 5 z 8 II 1921 r., poz. 92; ibidem, nr 49 z 13 XII 1921 r., poz. 872; ibidem, nr 33 z 19 VIII 1924 r., poz. 495.

${ }^{47}$ Tak podają autorzy Spisu byłych oddziałów Wojska Polskiego. Zob. także Spis byłych 
Grodzieńskich ${ }^{48}$. W październiku 1920 r., w składzie wojsk gen. Lucjana Żeligowskiego, wziął także udział w opanowaniu Wilna ${ }^{49}$. Swą ostateczną nazwę otrzymał po uzyskaniu we wrześniu 1933 roku prawa do używania szefostwa honorowego ${ }^{50}$. Pokojowym garnizonem pułku było Grodno ${ }^{51}$.

Oprócz nazwy, swe przywiązanie do historycznych ziem byłego Wielkiego Księstwa Litewskiego pułk wyraził również kształtem odznaki pamiątkowej, zatwierdzonej w grudniu 1921 roku $^{52}$. Odznaka o wymiarach $43 \times 27 \mathrm{~mm}$ mogła być wykonywana ze złota, srebra lub z białego metalu (alpaki) i miała kształt krzyża z wydłużonym ramieniem pionowym, otoczonego wieńcem laurowym. Na przecięciu ramion krzyża był nałożony herb w formie podzielonej na cztery pola okragłej tarczy, na której

oddziałów Wojska Polskiego, s. 96. Tymczasem w literaturze można napotkać informacje, że zmiana nazwy miała nastąpić jakoby już w 1919 r.

${ }^{48}$ W 1928 r. szef ówczesnego Wojskowego Biura Historycznego gen. brygady Julian Stachiewicz, oceniając propozycje nazw dla 80. i 81. oraz dla 85. i 86. Pułków Piechoty, napisał: „Pułki 80-y, 81-y, 85-y i 86-y pragną utrzymać tradycję swych zawiązków - »Samoobrony « na Kresach. Ponieważ jest to jedna i ta sama tradycja i pułki te w czasie wojny należały do jednej dywizji, 1-ej Litewsko-Białoruskiej, zmieniłem nieco nazwy, o jakie pułki proszą, by zachować jednolitość, podobnie jak przy pułkach 2-ej Dywizji Litewsko-Białoruskiej”. W przypadku nazwy tego oddziału generał proponował, aby otrzymała ona postać: 81 . Pułk Strzelców Grodzieńskich, a więc taką, jakiej pułk następnie rzeczywiście używał-zob. CAW, Wojskowe Biuro Historyczne, sygn. 341.1.52, Pismo szefa Wojskowego Biura Historycznego do szefa Biura Ogólnoorganizacyjnego MSWojsk. z 30 VI 1928 r.

49 Szerzej na temat jego dziejów zob.: J. Dąbrowski, Zarys historii wojennej 81-go Pułku Strzelców Grodzieńskich, Warszawa 1928; J. Lisicki, Strzelcy Grodzieńscy. 81 Pułk Strzelców Grodzieńskich im. Króla Stefana Batorego, Białystok 1995.

${ }^{50}$ Dziennik Rozkazów MSWojsk. nr 11 z 2 IX 1933 r., poz. 169; A. Smoliński, Szef czy patron-tradycja i wspótczesność w Wojsku Polskim, s. 521-522.

${ }^{51}$ Znajdując się w składzie wojsk Litwy Środkowej oraz w pierwszym okresie po jej inkorporacji do Rzeczypospolitej Polskiej pułk stacjonował w Wilnie. Po przeniesieniu do Grodna jego II Batalion stacjonował w Sokółce - zob.: CAW, Oddział II Sztabu Głównego, sygn. 303.4.92, Komunikat dyslokacyjny z wyszczególnieniem obecnych oraz już zarządzonych zmian miejsc postoju formacji wojskowych wszystkich rodzajów broni - Oddział I Sztabu Generalnego MSWojsk. L. 6607/O. de B. z 9 VI 1922 r.; ibidem, sygn. 302.4.139, Komunikat dyslokacyjny sił zbrojnych - Biuro Ogólnoorganizacyjne MSWojsk. L. 1150/ /Org. z 15 IX 1929 r.; ibidem, sygn. 303.4.214, Komunikat dyslokacyjny OK Nr III z dnia 1 stycznia 1927 r. - Oddział Ogólny Sztabu Dowództwa Okręgu Korpusu Nr III 1. dz. 9800. tjn. - Grodno w grudniu 1926 r.; CAW, Dowództwo Okręgu Korpusu VIII, sygn. 371.8.87, Komunikat dyslokacyjny dowództw dywizji piechoty, dywizji i brygad kawalerii oraz formacji ewidencyjnych wszystkich rodzajów broni - Biuro Ogólnoorganizacyjne MSWojsk. L. 3088/Org. z 21 IX 1926 r.

52 Dziennik Rozkazów MSWojsk. nr 49 z 13 XII 1921 r., poz. 872 -załącznik 2; Dziennik Rozkazów MSWojsk. nr 1 z 15 I 1929 r., poz. 1. 
znajdowały się Orzeł, Pogoń, niedźwiedź oraz Archanioł Michał ${ }^{53}$, z czerwonym krzyżem pośrodku emaliowanej na biało tarczy sercowej. Całość była zwieńczona stylizowaną złotą koroną jagiellońską ${ }^{54}$. Na krawędziach ramion krzyża znalazły się napisy: „GRODZIEŃSKI” (na górnym) oraz „P.STRZ.” (na dolnym), a także data powstania pułku: „12 LISTOP.” (na lewym) ${ }^{55}$ i ,1918 R.” (na prawym). Dwuczęściowa odznaka oficerska najczęściej była tłoczona z tombaku oraz złocona i emaliowana. Natomiast jej również dwuczęściową wersję dla szeregowych wykonywano z tombaku z tarczką srebrną ze złoceniami ${ }^{56}$.

Poza odznaką elementy tego typu występowały także na pułkowym sztandarze. Znak ten oddział otrzymał 6 czerwca 1921 roku w Wilnie, a jego fundatorem było społeczeństwo Grodna. Dnia 19 kwietnia następ-

${ }^{53} \mathrm{~W}$ ten sposób na odznace tej połączono używaną podczas powstania $1863 \mathrm{r}$. symbolikę dawnej Rzeczypospolitej złożonej z trzech prowincji, a mianowicie z Korony, Litwy i Rusi, do której dołączono także herb Żmudzi - zob. choćby: Powstanie styczniowe w zbiorach Muzeum Wojska Polskiego, oprac. W. Bigoszewska, M. Słoniewska, Warszawa 1966; J. I. Sztakelberg, Pieczęcie powstańcze 1863-1864, Warszawa 1988; S. Russocki, S. K. Kuczyński, J. Willaume, Godło, barwy i hymn Rzeczypospolitej. Zarys dziejów, Warszawa 1978; A. Znamierowski, Stworzony do chwaty, Warszawa 1995; Orzet Biały - 700 lat herbu państwa polskiego. 26 czerwca-15 października 1995. (Katalog wystawy na Zamku Królewskim w Warszawie), red. S. K. Kuczyński, Warszawa 1995.

${ }^{54}$ Henryk Wielecki oraz Rudolf Sieradzki (op. cit., s. 132) podają, że była to: „złota królewska korona zamknięta, wzorowana na koronie Stefana Batorego". Informacje te powtórzyli oni zapewne za: Ksiegga chwały piechoty... - metryka 81. Pułku Strzelców Grodzieńskich. W rzeczywistości była to raczej korona w swym rysunku oparta na regalium używanym powszechnie w herbie państwowym, co najmniej od czasów dwóch ostatnich Jagiellonów zasiadających na tronie polskim. Był to bowiem symbol świadczący o zupełnej niezawisłości politycznej rządzonego przez nich państwa oraz jednocześnie wizualny dowód realizacji przez tę dynastię idei wyrażonej w łacińskiej sentencji: rex imperator in regno suo. Ponadto z biegiem czasu korona taka stała się również jednym z symboli politycznej jedności Korony oraz Wielkiego Księstwa Litewskiego, a także innych ziem tworzących niegdyś Rzeczpospolitą Obojga Narodów - oprócz części wcześniej cytowanej literatury zob. choćby: M. Rożek, Polskie koronacje $i$ korony, Kraków 1987; Orty nasze. Orzet Biały w zbiorach Biblioteki Jagiellońskiej, red. M. Rokosz, Kraków 1996; Orzet Biały herb państwa polskiego. Materiały z sesji naukowej w dniach 27-28 czerwca 1995 roku na Zamku Królewskim w Warszawie, red. S. K. Kuczyński, Warszawa 1996; A. Znamierowski, Insygnia, symbole i herby polskie. Kompendium, Warszawa 2003; A. Jaworska, Orzet Biały herb państwa polskiego, Warszawa 2003.

${ }_{55} \mathrm{Na}$ lewym dla patrzącego na odznakę, a nie na lewym heraldycznie. Podobnie należy też rozumieć opis jej prawego ramienia krzyża.

56 Szerzej na temat tej odznaki zob.: M. Wełna, Odznaczenia i odznaki jednostek Wojska Polskiego 1914/1918-1939/1945, s. 59- poz. 351; H. Wielecki, R. Sieradzki, op. cit., s. 132; K. Filipow, B. Wróblewski-rysunki, op. cit., s. 67-68; Z. Sawicki, A. Wielechowski, op. cit., s. $129-130$. 
nego roku, również w Wilnie, choragiew ta została odznaczona przez Naczelnego Wodza Józefa Piłsudskiego Krzyżem Srebrnym Orderu Wojennego Virtuti Militari. Na lewym, białym płacie tego sztandaru był wyhaftowany zwrócony w lewo wizerunek klęczącego na dywanie i modlącego się świętego Kazimierza, patrona Wielkiego Księstwa Litewskiego ${ }^{57}$. W wyciągniętej ręce święty trzymał książęcą mitrę oraz berło, stanowiące jego atrybuty. Za nim, w prawej części płatu, znajdował się jeleń świętego Huberta - herb Grodna. Poza tym wzdłuż górnej krawędzi płata biegł napis: „NIE DAMY ZIEMI, SKĄD NASZ RÓD”, a wzdłuż dolnej: „TAK NAM DOPOMÓŻ BÓG!", które traktowano jako rycerskie zawołanie pułku.

Strona główna (prawa) tego znaku, z wyhaftowanym godłem państwowym w postaci białego Orła otoczonego złotym wieńcem laurowym, mieściła się w ramach obowiązujących wtenczas przepisów. Poza nazwą pułku wyhaftowaną na czerwonych ramionach krzyża kawalerskiego w postaci: „PUŁK 1” (dwa wiersze) - na górnym i „STRZELCÓW GRODZIEŃSKICH" (także dwa wiersze) - na dolnym, nie znalazły się tam żadne inne elementy świadczące o związkach tego oddziału z etosem ziem wchodzących niegdyś w skład Wielkiego Księstwa Litewskiego ${ }^{58}$. Obecnie sztandar ten, po wojennej tułaczce, podczas której poprzez konsulat RP w Kownie i Francję dotarł na Wyspy Brytyjskie, jest przechowywany w zbiorach Instytutu Polskiego i Muzeum imienia Generała Sikorskiego w Londynie ${ }^{59}$.

Następnym oddziałem kultywującym tradycje Wielkiego Księstwa Litewskiego był 85. Pułk Strzelców Wileńskich. Również jego historia w nierozerwalny sposób była związana z dziejami Samoobrony Wileńskiej, 1. Dywizji Litewsko-Białoruskiej oraz z „buntem” gen. Żeligowskiego ${ }^{60}$.

${ }^{57}$ Był to królewicz Kazimierz urodzony w 1458 r., syn króla Polski i wielkiego księcia litewskiego Kazimierza Jagiellończyka oraz Elżbiety Rakuszanki. Zmarł w 1484 r. Poza Litwą patronował również wileńskiej prowincji kościelnej, miastu Wilnu oraz młodzieży litewskiej, a także innym kresowym archidiecezjom i diecezjom. Jego święto połączone z hucznie obchodzonym w Wilnie i na Wileńszczyźnie odpustem zwanym „Kaziuki” przypada na 4 III - szerzej zob. U. Janicka-Krzywda, Patron - atrybut-symbol, Poznań 1993, s. 97.

${ }^{58}$ Na prawym ramieniu krzyża kawalerskiego znajdował się napis „HONOR I”, a na lewym „OJCZYZNA”. Natomiast na białych polach umieszczono numery „1” w złotych wieńcach laurowych.

${ }^{59}$ L. Mitkiewicz, Wspomnienia kowieńskie 1938-1939, Warszawa 1990, s. 342; J. Dąbrowski, op. cit., s. 47; Księga chwały piechoty... - metryka 81. Pułku Strzelców Grodzieńskich; K. Satora, op. cit., s. 150-154; J. Lisicki, op. cit., s. 33-34.

${ }^{60}$ Szerzej na temat dziejów tego pułku zob.: B. Waligóra, Zarys historii wojennej 85-go Pułku Strzelców Wileńskich, Warszawa 1928; idem, Dzieje 85 Pułku Strzelców Wileńskich, 
Początkowo był to Wileński Pułk Strzelców, formalnie przemianowany w 1919 roku na 85. Pułk Piechoty. Jednak już 14 października 1921 r. $^{61}$ oddział otrzymał swoją pierwotną nazwę i na powrót oficjalnie stał się 85. Pułkiem Strzelców Wileńskich. Urzędowe potwierdzenie tego faktu nastąpiło jednakże ponoć dopiero w 1938 roku $^{62}$. Jego pokojowym garnizonem była Nowowilejka ${ }^{63}$.

Oddział ten miał również dwie odznaki pamiątkowe, którymi wyraźnie nawiązywał do swego kresowego charakteru. Pierwszy wzór tego znaku, opracowany już w 1919 roku, został ustanowiony pismem ministra spraw wojskowych z 6 lutego 1921 roku, potwierdzonym następnie w listopadzie tego roku ${ }^{64}$. Jego projektantem był prof. Ferdynand Ruszczyc, ówczesny dziekan Wydziału Sztuk Pięknych Uniwersytetu Stefana Batorego w Wilnie. Odznaka miała postać okragłej tarczy ze znajdującym się na obrzeżu napisem: „KRESÓW NIE DAMY” oraz umieszczoną u dołu datą: „17 XII 18”, symbolizującą pierwotnie przyjęty czas powstania pułku. W górnej części tarczy znajdował się biały, mocno stylizowany Orzeł, a pod nim także stylizowana Pogoń, nałożona na małą tarczę herbową. Po ich bokach były litery „WP”. Tarcza leżała na skrzyżowanej maczudze oraz na łuku i kołczanie ze strzałami. Pomiędzy nimi, nad górną krawędzią tarczy, znajdował się stożkowaty hełm. Trudno jednak stwierdzić, czy ten wzór odznaki był nadawany, gdyż obecnie jest ona znana jedynie z projek-

Warszawa 1994 (wyd. 1 - Warszawa 1928); W. Markert, 85 Pułk Strzelców Wileńskich, Pruszków 2003.

${ }^{61}$ Tak podają autorzy Spisu byłych oddziałów Wojska Polskiego. Zob. także Spis byłych oddziałów Wojska Polskiego, s. 96. Tymczasem w literaturze można napotkać informacje, iż zmiana nazwy miała nastapić jakoby dopiero 15 VIII $1922 \mathrm{r}$.

${ }^{62}$ Tak podają: H. Wielecki, R. Sieradzki, op. cit., s. 136. Warto jednak pamiętać, że już w 1928 r. taką samą nazwę dla tego pułku proponował szef Wojskowego Biura Historycznego gen. brygady Julian Stachiewicz - zob. CAW, Wojskowe Biuro Historyczne, sygn. 341.1.52, Pismo szefa Wojskowego Biura Historycznego do szefa Biura Ogólnoorganizacyjnego MSWojsk. z 30 VI 1928 r.

${ }^{63}$ CAW, Oddział II Sztabu Głównego, sygn. 303.4.92, Komunikat dyslokacyjny z wyszczególnieniem obecnych oraz już zarządzonych zmian miejsc postoju formacji wojskowych wszystkich rodzajów broni - Oddział I Sztabu Generalnego MSWojsk. L. 6607/O. de B. z 9 VI 1922 r.; ibidem, sygn. 302.4.139, Komunikat dyslokacyjny sił zbrojnych - Biuro Ogólnoorganizacyjne MSWojsk. L. 1150/Org. z 15 IX 1929 r.; CAW, Dowództwo Okręgu Korpusu VIII, sygn. 371.8.87, Komunikat dyslokacyjny dowództw dywizji piechoty, dywizji i brygad kawalerii oraz formacji ewidencyjnych wszystkich rodzajów broni-Biuro Ogólnoorganizacyjne MSWojsk. L. 3088/Org. z 21 IX 1926 r.

${ }^{64}$ Dziennik Rozkazów MSWojsk. nr 49 z 13 XII 1921 r., poz. 872 - załącznik 2. 
tu rysunkowego, który został przedstawiony do zatwierdzenia ministrowi spraw wojskowych. Wzór ten, głównie z powodu nieścisłości heraldycznych, należy uznać na mało udany.

Nowa odznaka, o wymiarach $50 \times 44 \mathrm{~mm}^{65}$, została zatwierdzona już w marcu 1922 roku. Jednak odpowiedni rozkaz opublikowano dopiero w styczniu 1923 roku $^{66}$. Również tę odznakę zaprojektował prof. Ruszczyc. Przedstawiała ona ciekawie wystylizowanego srebrnego Orła w otwartej koronie, który trzymał w szponach emaliowany na niebiesko lub złocony ryngraf $z$ dwuwierszowym napisem pod górną jego krawędzią - „NIE DAMY"67 oraz nową datą powstania pułku, a mianowicie „20 XII 1918”68. Poniżej umieszczono wizerunek Matki Boskiej Ostrobramskiej. Odznaki dwuczęściowe wykonywano głównie z mosiądzu oraz srebrzono je i patynowano; ryngraf najczęściej złocono ${ }^{69}$.

W marcu 1927 roku pułk otrzymał także prawo do noszenia na kołnierzach kurtek oznaki w kształcie Pogoni (zob. tablica 2). Odpowiedni rozkaz ministra spraw wojskowych brzmiał:

przyznaję oficerom i szeregowym 85 P.P. oznakę „Pogoń litewska” na łapkach

[w rzeczywistości na patkach - przyp. A. S.] kołnierza kurtki.

Oficerowie noszą oznakę haftowaną nićmi z białego (srebrnego) galonu

[w rzeczywistości z bajorka - przyp. A. S.] [...].

Szeregowi noszą oznakę tłoczoną z blachy białego metalu ${ }^{70}$.

Oznaki te zwane też emblematami nie przekraczały zasadniczo $30 \mathrm{~mm}$ wysokości. Z reguły także, zgodnie z praktyką istniejącą w Wojsku Pol-

${ }_{65}$ M. Wełna (Odznaczenia i odznaki jednostek Wojska Polskiego 1914/1918-1939/1945, s. 60 - poz. 353a) przytacza inne wymiary, a mianowicie $51 \times 45 \mathrm{~mm}$. Jeszcze inne wymiary podają K. Filipow, B. Wróblewski - rysunki (op. cit., s. 71) $-51 \times 43 \mathrm{~mm}$.

${ }^{66}$ Dziennik Rozkazów MSWojsk. nr 3 z 30 I 1923 r., poz. 43.

${ }^{67}$ Było to nawiązanie do hasła „Kresów nie damy”, pod którym w końcu 1918 r. na Wileńszczyźnie oraz Mińszczyźnie i Grodzieńszczyźnie formowały się polskie oddziały Samoobrony Litwy i Białorusi.

${ }^{68} \mathrm{Na}$ części znanych obecnie odznak pamiątkowych tego wzoru brakuje jednak tego elementu.

${ }^{69}$ Szerzej na temat tych odznak zob.: M. Wełna, Odznaczenia i odznaki jednostek Wojska Polskiego 1914/1918-1939/1945, s. 59-60 - poz. 353a; H. Wielecki, R. Sieradzki, op. cit., s. 136-137; K. Filipow, B. Wróblewski - rysunki, op. cit., s. 70-71; Z. Sawicki, A. Wielechowski, op. cit., s. 135-136.

${ }^{70}$ Dziennik Rozkazów MSWojsk. nr 9 z 15 III 1927 r., poz. 73. Zob. także: ibidem, nr 22 z 4 VIII 1927 r., poz. 268, oraz ibidem, nr 24 z 30 VII 1930 r., poz. 286. 
skim Drugiej Rzeczypospolitej, podoficerowie zawodowi, podobnie jak oficerowie i chorążowie, nosili oznaki haftowane srebrnym bajorkiem ${ }^{71}$. Początkowo noszono je zarówno przy ubiorze polowym, jak i garnizonowym, a po 1936 roku już tylko przy mundurze garnizonowym w przypadku szeregowych i przy ubiorze garnizonowym służbowym oraz wieczorowym w przypadku oficerów i chorążych. Jednocześnie na prywatnych mundurach pozasłużbowych mogli je nosić także podoficerowie zawodowi ${ }^{72}$.

Ponadto, poza tymi zwyczajami, zapewne w celach estetycznych, Pogonie nakładane na prawe patki kołnierzy kurtek otrzymywały nieheraldyczny zwrot, gdyż prawidłowo powinny być one zwrócone w prawo. W ten sposób oznaki z obydwu stron kołnierzy były skierowane do przodu, w stronę zapięcia munduru (zob. tablica 2).

Oprócz opisanych powyżej oznak w postaci Pogoni oraz odznak pamiątkowych elementy tego typu występowały również na dwóch pułkowych sztandarach. Pierwszą choragiew 85. Pułk Strzelców Wileńskich otrzymał 29 września 1919 roku w Wilnie. Ufundowało ją społeczeństwo tego miasta, przede wszystkim Wileńskie Koło Polek. Na prawej stronie płatu, na czerwonym tle, znajdował się biały Orzeł z umieszczoną na tarczy litewską Pogonią na piersiach, a poniżej półokragły napis: „PUŁK STRZELCÓW WILEŃSKICH". Pod nim, w jednym wierszu, umieszczono kolejny napis, a mianowicie: „LIT.-BIAŁ. DYW.” Z kolei na odwrotnej stronie tego weksylium znajdował się wizerunek Matki Boskiej Ostrobramskiej w okrągłym medalionie. Dnia 19 kwietnia 1922 roku na Placu Łukiskim w Wilnie ta nieprzepisowa choragiew pułku została udekorowana przez Marszałka Józefa Piłsudskiego Krzyżem Srebrnym Orderu Wojennego Virtuti Militari. Swoją służbę najświętszego symbolu oddziału znak ten pełnił do 1928 roku, po czym został zdeponowany w pułkowym muzeum ${ }^{73}$. Po wojennej

${ }^{71}$ R. Medwicz, Polski mundur wojskowy w przededniu II wojny światowej, „Studia i Materiały do Dziejów Dawnego Uzbrojenia i Ubioru Wojskowego", 1978, t. 7, s. 134-135. Ponadto zob. również S. Komornicki, Z. Bielecki, W. Bigoszewska, A. Jońca-rysunki, Wojsko Polskie 1939-1945. Barwa i broń, Warszawa 1984.

72 Przepis ubioru polowego Wojsk Polskich r. 1919, Ministerstwo Spraw Wojskowych, Warszawa 1920; Dziennik Rozkazów MSWojsk. nr 19 z 17 VI 1929 r., poz. 187. Zob. także: R. Saxl, Umundurowanie Wojska Polskiego, Warszawa 1928; H. Wielecki, Polski mundur wojskowy 1918-1939, Warszawa 1995.

${ }^{73}$ Zgodnie z brzmieniem oficjalnych przepisów obowiązujących w tej kwestii w armii Drugiej Rzeczypospolitej wszystkie nieprzepisowe choragwie i sztandary oraz inne weksylia miały być przekazywane do zbiorów ówczesnego Muzeum Wojska w Warszawie, skąd mogły 
tułaczce sztandar ten ostatecznie znalazł się w Muzeum Wojska Polskiego w Warszawie, gdzie jest przechowywany po dzień dzisiejszy ${ }^{74}$.

Nowy sztandar, tym razem przepisowy ${ }^{75}$, pułk otrzymał w Wilnie dnia 23 września 1928 roku. Po raz kolejny jego fundatorami byli mieszkańcy Wilna. Wygląd jego lewej (odwrotnej) strony 16 września tego roku został zatwierdzony przez ministra spraw wojskowych zarządzeniem L. 1644/28 ${ }^{76}$. Poza hasłem „HONOR I OJCZYZNA” umieszczonym w złotym wieńcu laurowym oraz złożonym z dwóch wierszy napisem „RADZYMIN" - „15-VIII-1920”, pomiędzy ramionami krzyża kawalerskiego znalazły się również: w prawym górnym rogu czerwona tarcza ze Słupami Giedymina, w lewym górnym rogu, także na czerwonej tarczy, Pogoń, w prawym dolnym rogu tarcza z podobizną świętego Krzysztofa, a w lewym dolnym rogu tarcza $z$ wizerunkiem Matki Boskiej Ostrobramskiej ${ }^{77}$. Trzeba zauważyć, że trzy z wymienionych powyżej symboli nawiązywały do etosu ziem stanowiących część dawnego Wielkiego Księstwa Litewskiego, a dwa z nich do jego państwowej symboliki. Wygląd prawej strony tego sztandaru nie odbiegał od obowiązujących w tej kwestii przepisów. Obecnie weksylium to przechowywane jest w zbiorach Muzeum Wojska Polskiego w Warszawie ${ }^{78}$.

Do etosu dawnego Wielkiego Księstwa Litewskiego nawiązywano także w 86. Pułku Piechoty. Również dzieje tego oddziału były związane najpierw z Samoobroną Litwy i Białorusi, a konkretnie z Samoobroną Ziemi Mińskiej, a następnie z 1. Dywizją Litewsko-Białoruską, w szeregach której pułk ten walczył podczas wojny polsko-sowieckiej, a potem, już po jego przemianowaniu na 19. Dywizję Piechoty, wziął udział w „buncie”

być wypożyczane do muzeów pułkowych na zasadzie depozytów - zob. Dziennik Rozkazów MSWojsk. nr 36 z 25 IX 1923 r., poz. 461.

${ }^{74}$ B. Waligóra, Zarys historii wojennej 85-go Pułku Strzelców Wileńskich, s. 31; idem, Dzieje 85 Pułku Strzelców Wileńskich, s. 128, 410; K. Satora, op. cit., s. 161-164; W. Markert, 85 Pułk Strzelców Wileńskich, s. 34.

${ }^{75}$ W 1927 r. do poprzednio obowiązujących przepisów w tej kwestii wprowadzono pewne zmiany polegające między innymi na zmianie rysunku godła państwowego umieszczanego na sztandarach - zob.: Dziennik Ustaw RP nr 115 z 18 XII 1927 r., poz. 980 - Rozporządzenie Prezydenta Rzeczypospolitej z dnia 13 grudnia 1927 r. o godłach i barwach państwowych oraz o oznakach, chorągwiach i pieczęciach, oraz Dziennik Rozkazów MSWojsk. nr 11 z 1 V 1928 r., poz. 129.

${ }^{76}$ Dziennik Rozkazów MSWojsk. nr 31 z 8 XI 1928 r., poz. 340.

77 K. Satora, op. cit., s. 161-164; W. Markert, 85 Pułk Strzelców Wileńskich, s. 34.

${ }^{78}$ K. Satora, op. cit., s. 161-164. 
gen. Żeligowskiego. Początkowo istniał jako Miński Pułk Strzelców, a 12 października 1921 roku $^{79}$ otrzymał nazwę 86. Pułk Piechoty ${ }^{80}$. Jego pokojowym garnizonem było Mołodeczno. Jedynie III Batalion stacjonował w Krasnem ${ }^{81}$.

Wzór odznaki pamiątkowej pułku został opracowany w 1919 roku i przyjęty, wraz z regulaminem, na zebraniu oficerskim 30 grudnia tego ro$\mathrm{ku}^{82}$. Odznaka o wymiarach $47 \times 30 \mathrm{~mm}$ miała kształt pokrytego białą emalią ${ }^{83}$ krzyża łacińskiego ze złotą obwódką. Pośrodku krzyża był nałożony srebrny, stylizowany Orzeł w koronie o szeroko rozłożonych skrzydłach. W szponach trzymał tarczę herbową ziemi mińskiej, emaliowaną w skos w czarno-białe pasy. Ramiona krzyża oplatał złoty wieniec laurowy. Ponadto na jego dolnym ramieniu była umieszczona data powstania pułku: „19” - „17 XII” (w dwóch wierszach) - „,18”. Odznaka jednakowego wzoru zarówno dla oficerów, jak i szeregowych była jedno- lub dwuczęściowa,

79 Tak podają autorzy Spisu byłych oddziałów Wojska Polskiego. Zob. także Spis byłych oddziałów Wojska Polskiego, s. 96. W literaturze można napotkać natomiast informacje, że zmiana nazwy pułku nastąiła już 1 X 1921 r. Tak podaje S. Mieczkowski, Zarys historii wojennej 86-go Pułku Piechoty, Warszawa 1929, s. 38.

${ }^{80}$ Takiej skróconej nazwy pułk używał, pomimo że w 1928 r. szef Wojskowego Biura Historycznego gen. brygady Julian Stachiewicz, oceniając propozycje nazewnictwa pułków byłej 1. Dywizji Litewsko-Białoruskiej, zaproponował dla niego nazwę w postaci: 86 . Pułk Strzelców Mińskich - zob. CAW, Wojskowe Biuro Historyczne, sygn. 341.1.52, Pismo szefa Wojskowego Biura Historycznego do szefa Biura Ogólnoorganizacyjnego MSWojsk. z 30 VI 1928 r. Szerzej na temat dziejów tego oddziału zob. S. Mieczkowski, op. cit.; W. Markert, 86 Pułk Piechoty, Pruszków 1994.

${ }^{81}$ Znajdując się w składzie wojsk Litwy Środkowej oraz w pierwszym okresie po jej inkorporacji do Rzeczypospolitej Polskiej pułk stacjonował w Wilnie - zob. CAW, Oddział II Sztabu Głównego, sygn. 303.4.92, Komunikat dyslokacyjny z wyszczególnieniem obecnych oraz już zarządzonych zmian miejsc postoju formacji wojskowych wszystkich rodzajów broni - Oddział I Sztabu Generalnego MSWojsk. L. 6607/O. de B. z 9 VI 1922 r.; ibidem, sygn. 302.4.139, Komunikat dyslokacyjny sił zbrojnych - Biuro Ogólnoorganizacyjne MSWojsk. L. 1150/ /Org. z 15 IX 1929 r.; ibidem, sygn. 303.4.214, Komunikat dyslokacyjny OK. Nr III z dnia 1 stycznia 1927 r. - Oddział Ogólny Sztabu Dowództwa Okręgu Korpusu Nr III 1. dz. 9800. tjn. - Grodno w grudniu 1926 r.; CAW, Dowództwo Okręgu Korpusu VIII, sygn. 371.8.87, Komunikat dyslokacyjny dowództw dywizji piechoty, dywizji i brygad kawalerii oraz formacji ewidencyjnych wszystkich rodzajów broni - Biuro Ogólnoorganizacyjne MSWojsk. L. 3088/Org. z 21 IX 1926 r.

${ }^{82}$ Wydaje się, że za moment jej oficjalnego zatwierdzenia należy uznać maj 1929 r., kiedy to minister spraw wojskowych zaakceptował regulamin odznaki, sankcjonując tym samym jej kształt - zob. Dziennik Rozkazów MSWojsk. nr 16 z 18 V 1929 r., poz. 159.

${ }^{83}$ Barwa ta miała stanowić ,godło wiary świadczącej o czystości dążeń”. 
tłoczona $\mathrm{z}$ tombaku lub ze srebra oraz złocona i emaliowana. Niekiedy wieniec i korona Orła były złocone ${ }^{84}$.

Poza odznaką pamiątkową elementy tego typu występowały też na pułkowym sztandarze ufundowanym przez obywateli Mińska oraz ziemi mińskiej i wręczonym oddziałowi 18 marca 1921 roku w Wilnie ${ }^{85}$. Dnia 19 kwietnia 1922 roku, również w Wilnie, na Placu Łukiskim ta nieprzepisowa choragiew, wraz ze sztandarami trzech innych pułków byłej 1. Dywizji Litewsko-Białoruskiej, została udekorowana przez Marszałka Józefa Piłsudskiego Krzyżem Srebrnym Orderu Wojennego Virtuti Militari. Na prawym (głównym), czerwonym płacie sztandaru znajdowały się wyhaftowane białą nicią dwie splecione ze sobą tarcze $\mathrm{z}$ herbami Korony - Orłem stylizowanym na godło z okresu ostatnich Jagiellonów oraz z litewską Pogonią. Tarcze miały zaznaczone jedynie kontury, a ich pola stanowił płat choragwi.

$\mathrm{Na}$ białej stronie lewej (odwrotnej) sztandaru, pośrodku, umieszczono barwny herb Mińska wzorowany na pieczęci miejskiej z 1569 roku. Stąd też wokół jego wizerunku znalazł się łaciński napis: „SIGILLUM CIVITATIS MINSCENSIS ANNO 1569". Natomiast po obu bokach tego herbu znajdowała się data „1919” podzielona na dwie części. Ponad herbem mieściła się dwuwierszowa inskrypcja w postaci: „Miasto Mińsk $6^{\mathrm{mu}}$ Mińskiemu pułkowi Strzelców". Tej samej treści napis w języku białoruskim, jednak sporządzony z użyciem alfabetu łacińskiego, znalazł się poniżej herbu. Otrzymał on postać: „Miesto Miensk $6^{\mathrm{mu}}$ Mienskamu połku Stralcoū”. Po wojennej tułaczce, poprzez konsulat Rzeczypospolitej Polskiej w Kownie, sztandar ten trafił najpierw do Francji, a następnie do Anglii. Obecnie jest przechowywany w zbiorach Instytutu Polskiego i Muzeum imienia Generała Sikorskiego w Londynie ${ }^{86}$.

Wspomniana powyżej Pogoń oraz herb Mińska były najistotniejszymi umieszczonymi na sztandarze elementami świadczącymi o związkach

${ }^{84}$ Szerzej na temat tej odznaki zob.: M. Wełna, Odznaczenia i odznaki jednostek Wojska Polskiego 1914/1918-1939/1945, s. 60 - poz. 354; H. Wielecki, R. Sieradzki, op. cit., s. 138; K. Filipow, B. Wróblewski - rysunki, op. cit., s. 72; Z. Sawicki, A. Wielechowski, op. cit., s. $136-137$.

${ }^{85}$ Było to jedno z dwóch weksyliów tego typu, posiadanych przez 86 . Pułk Piechoty. Jednakże właściwe funkcje sztandaru pułkowego, aż do 1939 r., spełniał znak opisany powyżej. Natomiast drugi z nich już w 1924 r. został przekazany do Muzeum Wojskowego - zob.: S. Mieczkowski, op. cit., s. 38; W. Markert, 86 Putk Piechoty, s. 37.

${ }^{86}$ Księga chwaty piechoty... - metryka 86. Pułku Piechoty; S. Mieczkowski, op. cit., s. 38; K. Satora, op. cit., s. 164-165; W. Markert, 86 Pułk Piechoty, s. 37 oraz fotografia barwna z ostatniej strony okładki. 
85. Pułku Piechoty z tradycją ziem dawnego Wielkiego Księstwa Litewskiego.

Choć dzieje kolejnych dwóch oddziałów wiązały się z historią i szlakiem bojowym 1. bądź 2. Dywizji Litewsko-Białoruskiej, to po 1921 roku w znacznie mniejszym stopniu nawiązywały one do tradycji ziem wchodzących w skład byłego Wielkiego Księstwa Litewskiego. Pierwszym z nich był późniejszy 78. Pułk Piechoty, który został sformowany dopiero w kwietniu 1920 roku na bazie utworzonego w lutym tego roku Batalionu Zapasowego Słuckiego Pułku Strzelców. Wówczas powstał bowiem Słucki Pułk Strzelców. Po stratach, które poniósł w walkach z Armią Czerwoną latem 1920 roku, w pierwszych dniach sierpnia na krótko został rozwiazany, ale jeszcze w tym samym miesiącu rozpoczęło się jego odtwarzanie w Kaliszu oraz w Modlinie. Wiosną roku następnego przemianowano go na 78 Pułk Piechoty ${ }^{87}$, a na pokojowy garnizon wyznaczono Baranowi$\mathrm{cze}^{88}$. Niekiedy, jeszcze w końcu lat 20., nieformalnie używano w pułku niezatwierdzonej ostatecznie przez ministra spraw wojskowych nazwy 78. Słucki Pułk Piechoty ${ }^{89}$.

Zapewne stosunkowo krótka przeszłość bojowa tej formacji oraz inne czynniki spowodowały, że poza pierwotną i na dodatek w końcu zarzuconą nazwą nie eksponowano w niej zbytnio potencjalnych związków z tradycją byłego Wielkiego Księstwa Litewskiego. Żaden element tego rodzaju symboliki nie znalazł się bowiem na odznace pamiątkowej pułku ${ }^{90}$. Jedy-

${ }^{87}$ Mimo to w 1928 r. szef Wojskowego Biura Historycznego gen. brygady Julian Stachiewicz zaproponował dla niego nazwę w postaci: 78. Pułk Strzelców Słuckich - zob. CAW, Wojskowe Biuro Historyczne, sygn. 341.1.52, Pismo szefa Wojskowego Biura Historycznego do szefa Biura Ogólnoorganizacyjnego MSWojsk. z 30 VI 1928 r.

${ }^{88}$ CAW, Oddział II Sztabu Głównego, sygn. 303.4.92, Komunikat dyslokacyjny z wyszczególnieniem obecnych oraz już zarządzonych zmian miejsc postoju formacji wojskowych wszystkich rodzajów broni - Oddział I Sztabu Generalnego MSWojsk. L. 6607/O. de B. z 9 VI 1922 r.; ibidem, sygn. 302.4.139, Komunikat dyslokacyjny sił zbrojnych - Biuro Ogólnoorganizacyjne MSWojsk. L. 1150/Org. z 15 IX 1929 r.; CAW, Dowództwo Okręgu Korpusu VIII, sygn. 371.8.87, Komunikat dyslokacyjny dowództw dywizji piechoty, dywizji i brygad kawalerii oraz formacji ewidencyjnych wszystkich rodzajów broni-Biuro Ogólnoorganizacyjne MSWojsk. L. 3088/Org. z 21 IX 1926 r.

${ }^{89}$ Obszerniej na temat dziejów tego oddziału zob.: Spis byłych oddziałów Wojska Polskiego; Spis byłych oddziałów Wojska Polskiego; S. Szabłowski, F. Suchomel, Zarys historii wojennej 78-go Stuckiego Putku Piechoty, Warszawa 1929; W. Jarno, Okręg Korpusu Wojska Polskiego Nr IV Łódź 1918-1939, Łódź 2001

${ }^{90}$ Na temat jej wyglądu zob. choćby: H. Wielecki, R. Sieradzki, op. cit., s. 128; K. Filipow, B. Wróblewski-rysunki, op. cit., s. 65-66; Z. Sawicki, A. Wielechowski, op. cit., s. 125-126. 
nie na ufundowanym dla niego w 1923 roku przez mieszkańców ziemi baranowickiej i miasta Baranowicze sztandarze ${ }^{91}$ znalazły się: „herby Litwy i Białorusi, które nawiązują do pierwotnych założeń organizacyjnych i ideowych Pułku"92. W rzeczywistości na stronie lewej (odwrotnej) tego zna$\mathrm{ku}, \mathrm{w}$ rogach płata, mieściły się wizerunki Matki Boskiej Ostrobramskiej (w prawym górnym i lewym dolnym), a w pozostałych rogach dzielone pionowo na pół tarcze z Pogonią i świętym Michałem ${ }^{93}$. Obecnie po ocaleniu z wojennej zawieruchy sztandar ten znajduje się w zbiorach Muzeum Wojska Polskiego w Warszawie ${ }^{94}$.

Podobnie było w przypadku 80. Pułku Piechoty. Powstał on dopiero w lipcu 1919 roku z Batalionu Uzupełnień 1. Dywizji Litewsko-Białoruskiej. Do kwietnia następnego roku udało się sformować zaledwie jeden batalion ówczesnego Nowogródzkiego Pułku Strzelców. Dopiero latem 1920 roku zorganizowano dwa kolejne bataliony. Następnie pułk w składzie 1. Dywizji Litewsko-Białoruskiej walczył przeciwko Armii Czerwonej, a w październiku tego roku uczestniczył w „buncie” gen. Żeligowskiego. Dnia 12 października 1921 roku $^{95}$ przemianowano go na 80 . Pułk Piechoty ${ }^{96}$, przydzielając go jednocześnie do 20. Dywizji Piechoty ${ }^{97}$. Od 1922 roku stacjonował w Słonimiu ${ }^{98}$.

${ }^{91}$ S. Szabłowski, F. Suchomel, op. cit., s. 16.

${ }^{92}$ Księga chwaty piechoty...-metryka 78. Pułku Piechoty.

93 Wygląd jej lewej strony został zatwierdzony przez Prezydenta Rzeczypospolitej Polskiej dekretem L. 509/23 z 16 IV 1923 r. - zob. Dziennik Rozkazów MSWojsk. nr 43 z 13 XI 1923 r., poz. 555.

94 Zob. K. Satora, op. cit., s. 145-147.

${ }^{55}$ Tak podają autorzy Spisu byłych oddziałów Wojska Polskiego. Zob. także Spis bytych oddziałów Wojska Polskiego, s. 96. Tymczasem w literaturze można napotkać informacje, że zmiana nazwy nastąpiła już wiosną $1921 \mathrm{r}$.

${ }^{96}$ L. Jędrzejczyk (Zarys historii wojennej 80-go Pułku Strzelców Nowogródzkich, Warszawa 1930, s. 55) podaje jednak, że pułk przemianowano wówczas na 80. Pułk Strzelców Nowogródzkich. Fakt ten potwierdzają również autorzy Spisu byłych oddziałów Wojska Polskiego, zob. teżSpis bylych oddziałów Wojska Polskiego, s. 96. Ponadto nazwę w takiej postaci w 1928 r. poparł także szef Wojskowego Biura Historycznego gen. brygady Julian Stachiewicz - zob. CAW, Wojskowe Biuro Historyczne, sygn. 341.1.52, Pismo szefa Wojskowego Biura Historycznego do szefa Biura Ogólnoorganizacyjnego MSWojsk. z 30 VI 1928 r.

${ }^{97}$ Powstała ona z części pułków byłej 2. Dywizji Litewsko-Białoruskiej. Szerzej na temat dziejów tego pułku zob.: Spis byłych oddziałów Wojska Polskiego; Spis bylych oddziałów Wojska Polskiego; L. Jędrzejczyk, op. cit.

${ }^{98}$ CAW, Oddział II Sztabu Głównego, sygn. 303.4.92, Komunikat dyslokacyjny z wyszczególnieniem obecnych oraz już zarządzonych zmian miejsc postoju formacji wojskowych wszystkich rodzajów broni-Oddział I Sztabu Generalnego MSWojsk. L. 6607/O. de B. z 9 VI 
Zgodnie z oficjalną wersją dziejów tego oddziału pierwotna nazwa Nowogródzki Pułk Strzelców:

nawiązująca do chwalebnej przeszłości Nowogródka, jako miasta wojewódzkiego, jeszcze w czasach przedrozbiorowych, następnie do ziemi, która dała narodowi największego z nieśmiertelnych wieszczów naszych, Adama Mickiewicza, oparta była głównie na tym, że ponad 50 procent ochotników wcielanych do organizującego się pułku [...] pochodziło właśnie z obszarów leżących w granicach województwa tej nazwy z czasów przedrozbiorowych [czyli z okresu istnienia Wielkiego Księstwa Litewskiego jako integralnej części Rzeczypospolitej Obojga Narodów - przyp. A. S.]. W nazwie pułku odżyła, jak widzimy, stara, świetna tradycja miasta Nowogródka, celowo skasowana przez zaborców w czasach niewoli ${ }^{99}$.

Pomimo tej pierwotnej nazwy na odznace pamiątkowej pułku nie znalazły się jednak żadne elementy świadczące o jego związkach z Nowogródczyzną czy też szerzej - z etosem dawnego Wielkiego Księstwa Litewskiego ${ }^{100}$.

Znajdowały się one natomiast na pierwszym jego sztandarze, który został mu wręczony w Bobrujsku 19 grudnia 1919 roku przez generała broni Stanisława Szeptyckiego, ówczesnego dowódcę Frontu Litewsko-Białoruskiego. Choragiew ta

przedstawiająca na jednej stronie płachty [na jej stronie prawej (głównej) przyp. A. S.], wyhaftowane na amarancie Orła Białego i Pogoń, na jednej tarczy Jagiellońską koroną złączone; na drugiej zaś [czyli na stronie lewej (odwrotnej) - przyp. A. S.] wizerunek Matki Boskiej Ostrobramskiej, z napisem: „Matko Ziem Polskich - Módl się za nami" - była darem Związku Kobiet Kresowych „Pogoń” w Wilnie. Choragiew ta była przeznaczona dla jednego z zasłużonych oddziałów przy oswobadzaniu Kresów, według uznania dowódcy

1922 r.; ibidem, sygn. 302.4.139, Komunikat dyslokacyjny sił zbrojnych - Biuro Ogólnoorganizacyjne MSWojsk. L. 1150/Org. z 15 IX 1929 r.; CAW, Dowództwo Okręgu Korpusu VIII, sygn. 371.8.87, Komunikat dyslokacyjny dowództw dywizji piechoty, dywizji i brygad kawalerii oraz formacji ewidencyjnych wszystkich rodzajów broni-Biuro Ogólnoorganizacyjne MSWojsk. L. 3088/Org. z 21 IX 1926 r.

${ }_{99}$ L. Jędrzejczyk, op. cit., s. 6.

100 Na temat jej wyglądu zob. choćby: M. Wełna, Odznaczenia i odznaki jednostek Wojska Polskiego 1914/1918-1939/1945, s. 59-poz. 350; H. Wielecki, R. Sieradzki, op. cit., s. 131; K. Filipow, B. Wróblewski - rysunki, op. cit., s. 67; Z. Sawicki, A. Wielechowski, op. cit., s. $128-129$. 
frontu - generała Szeptyckiego. Zaszczyt ten i niemałe wyróżnienie, osiągnięte przez Nowogródzki pułk, przyjęte zostało w szeregach wiarusów nowogródzkich z ogromną radościąi ${ }^{101}$.

Z powyższego wynika, że Nowogródzki Pułk Strzelców stał się posiadaczem tej choragni w sposób nieco przypadkowy. Tego nieprzepisowego wtenczas znaku używał oddział do 1923 roku, kiedy to przekazano go do zbiorów ówczesnego Muzeum Wojska w Warszawie.

Wtedy też pułk otrzymał nową, przepisową choragiew ${ }^{102}$, ufundowaną staraniem komitetu złożonego z przedstawicieli ziemi nowogródzkiej z ówczesnym wojewodą Władysławem Raczkiewiczem i starostą nowogródzkim Jellinkiem na czele ${ }^{103}$. Obok odpowiednich napisów w prawym i lewym górnym rogu lewej strony płatu sztandarowego umieszczono przedrozbiorowe herby Nowogródka i województwa nowogródzkiego ${ }^{104}$, a w prawym dolnym rogu wizerunek świętego Ładysława z Gielniowa wybranego na patrona pułku ${ }^{105}$, gdyż w dniu tego świętego nastapił jego chrzest bojowy. Natomiast w lewym dolnym rogu znajdował się obraz Matki Boskiej Ostrobramskiej ${ }^{106}$. Sztandar ten, wskutek złych warunków przechowywania podczas drugiej wojny światowej, uległ zniszczeniu i poza Orłem oraz gwoździami nie dotrwał do naszych czasów ${ }^{107}$.

Opisane powyżej sztandary pułków piechoty nie były jedynymi znakami tego typu, na których znalazły się jakieś elementy symboliki nawiązującej do tradycji ziem byłego Wielkiego Księstwa Litewskiego. W czerwcu 1923 roku 41. Suwalski Pułk Piechoty Marszałka Józefa Pilsudskiego otrzymał sztandar: „ufundowany przez ludność powiatów suwalskiego

\footnotetext{
${ }^{101}$ L. Jędrzejczyk, op. cit., s. 15-16.

102 Wygląd jej lewej strony został zatwierdzony przez Prezydenta Rzeczypospolitej Polskiej dekretem L. 743/1923 z 12 VI 1923 r. - zob. Dziennik Rozkazów MSWojsk. nr 27 z 24 VII 1923 r., poz. 359.

${ }^{103}$ L. Jędrzejczyk, op. cit., s. 56.

104 Herb tego województwa przedstawiał dwudzielną czerwoną tarczę. Jej prawe pole zajmowała Pogoń, a lewe archanioł.

105 Ten urodzony około 1440 r. w rodzinie mieszczańskiej bernardyn, najpierw z krakowskiego, a potem z warszawskiego konwentu, jako błogosławiony, uważany jest także za patrona Polski i Warszawy, a obecnie również za patrona diecezji szczecińsko-kamieńskiejzob. U. Janicka-Krzywda, op. cit., s. 98.

${ }_{106}$ Ksiegga chwały piechoty... - metryka 80. Pułku Piechoty.

107 Jego pozostałości w 1959 r. trafiły do Muzeum Ziemi Zawkrzeńskiej w Mławie-zob. K. Satora, op. cit., s. 149-150.
} 
i augustowskiego. Uwiecznione na nim zostały miejscowości, gdzie Pułk stoczył największe boje [na stronie lewej (odwrotnej) - przyp. A. S.]. Ponadto widnieją na nim Pogoń litewska oraz herb Lidy [w lewym dolnym rogu - przyp. A. S.], gdzie po stoczonej bitwie Naczelny Wódz zgodził się na przyjęcie Szefostwa Pułku"108.

Podobnie było też ze sztandarem 42. Pułku Piechoty imienia Generała Jana Henryka Dąbrowskiego, który oddział ten otrzymał z rąk Pierwszego Marszałka Polski Józefa Piłsudskiego 21 sierpnia 1921 roku w Białymstoku. Jednak wygląd jego lewej (odwrotnej) strony został ostatecznie zatwierdzony dopiero w lutym 1939 roku. W odpowiednim rozkazie Departamentu Dowodzenia Ogólnego Ministerstwa Spraw Wojskowych nakazano wtedy: „Dotychczasowy wzór lewej strony płatu sztandaru [...] uzupełnić następującymi emblematami i napisami:

- w prawym górnym rogu na tarczy - wizerunek Matki Boskiej Ostrobramskiej,

- w lewym górnym rogu na tarczy - godło miasta ${ }^{109}$ Białegostoku"110.

Tak samo było również w przypadku 79. Pułku Piechoty. Na lewej (odwrotnej) stronie, w prawym górnym rogu płatu jego sztandaru wyhaftowano bowiem herb Nowogródka, w lewym górnym rogu herb Słonimia, w prawym dolnym wizerunek patrona Białorusi świętego Michała, a w lewym dolnym rogu Matkę Boską Ostrobramską. Jak w końcu lat 30. napisano w metryce tego oddziału zamieszczonej w Księdze chwaty piechoty: „Znaki te symbolizują ścisłą łączność duchową 79. Pułku Piechoty z ziemią, z której Pułk się wywodzi i na której staczał swe pierwsze boje. Sztandar został ufundowany przez społeczeństwo ziemi słonimskiej"111.

${ }^{108}$ Księga chwały piechoty...-metryka 41. Suwalskiego Pułku Piechoty Marszałka Józefa Piłsudskiego.

109 Jednym z elementów tego herbu była Pogoń występująca tam obok polskiego białego Orła. Taki sam herb znajdował się także na pułkowej odznace pamiątkowej-zob.: M. Wełna, Odznaczenia i odznakijednostek Wojska Polskiego 1914/1918-1939/1945, s. 52-53 - poz. 321; H. Wielecki, R. Sieradzki, op. cit., s. 80; K. Filipow, B. Wróblewski - rysunki, op. cit., s. 67; Z. Sawicki, A. Wielechowski, op. cit., s. 82-83.

110 Dziennik Rozkazów MSWojsk. nr 2 z 23 II 1939 r., poz. 20. Szerzej na temat dziejów tej formacji zob.: J. Żołna, Zarys historii wojennej 42-go Pułku Piechoty, Warszawa 1929; A. Dobroński, K. Filipow, „Dzieci Białostockie”. 42 Pułk Piechoty im. gen. Jana Henryka Dąbrowskiego, Białystok 1993; iidem, 42 Pułk Piechoty im. gen. Jana Henryka Dąbrowskiego, Białystok 1996.

${ }^{111}$ Księga chwaty piechoty... - metryka 79. Pułku Piechoty. Szerzej na temat dziejów tego pułku zob. M. Różycki, S. Dybkowski, Zarys historii wojennej 79-go Pułku Piechoty, Warszawa 1929. 
Ponadto Pogoń znajdowała się także na lewej stronie sztandaru 82. Syberyjskiego Pułku Strzelców imienia Tadeusza Kościuszki ${ }^{112}$. Jednak w przeciwieństwie do wcześniej omówionych formacji żaden z tych oddziałów nie kultywował w jakiś szczególny sposób swoich związków historycznych z tradycją i etosem ziem wchodzących niegdyś w skład Wielkiego Księstwa Litewskiego, stanowiącego część potężnej Rzeczypospolitej Obojga Narodów.

Nie należy też wykluczać, że jakieś elementy symboliki omawianego tutaj typu występowały również na innych przedmiotach stanowiących integralną część tradycji poszczególnych oddziałów. Tak bowiem mogło być choćby z biżuterią pułkową, a także z płomieniami do fanfar ${ }^{113}$, fartuchami do instrumentów perkusyjnych itd.

Trzeba również pamiętać, że w okresie międzywojennym, poza poprzednio opisanymi odznakami, litewska Pogoń lub też podwójny krzyż jagielloński znalazły się także na odznace pamiątkowej Frontu Litewsko-Białoruskiego, a Pogoń - na „Krzyżu Dywizji Litewsko-Białoruskiej”. Podobnie było też z odznaką pamiątkową Dywizji Podlaskiej, czyli „Krzyżem Dywizji Podlaskiej”, oraz z odznaką tej samej dywizji, zwaną „Za Męstwo", gdzie na trójpolowej tarczy wystapiła ona obok Orła i Archanioła Michała. Pogoń znalazła się też na odznace pamiątkowej „Zajęcie Wilna 19 IV 1919 r." 114 Na trójpolowej tarczy była również na odznace pamiątkowej „Obrońcom Kresów Wschodnich”, a na tarczy trzymanej w szponach przez Orła na odznace pamiątkowej Wojsk Litwy Środkowej i na „Krzyżu Zasługi Wojsk Litwy Środkowej”. Poza tym umieszczona na tarczy, po lewej stronie Orła, Pogoń stanowiła także oficjalny herb Litwy Środkowej. Na jego podstawie w 1920 roku i w kolejnych dwóch latach wykonywano różnorodne oznaki pamiątkowe, często noszone przez żołnierzy Wojsk Litwy Środkowej ${ }^{115}$.

${ }_{112}$ Księga chwały piechoty...-metryka 82. Syberyjskiego Pułku Piechoty. Na temat dziejów tego oddziału zob. F. Dindor-Ankowicz, Zarys historii wojennej 82-go Syberyjskiego Putku Piechoty, Warszawa 1929.

${ }^{113}$ Oficjalne przepisy dotyczące tej kwestii ustalały rozkazy ministra spraw wojskowych zamieszczane w Dziennikach Rozkazów - zob. choćby: Dziennik Rozkazów MSWojsk. nr 11 z 18 III 1924 r., poz. 160 - dotyczył jednak tylko kawalerii i artylerii konnej, a także ibidem, nr 26 z 3 VIII 1929 r., poz. 259, oraz ibidem, nr 10 z 22 VI 1939 r., poz. 95. Należy jednak pamiętać, że bardzo często wygląd tych weksyliów znacznie odbiegał od powyższych zarządzeń i ustalanych nimi zasad.

114 Zwana też, najprawdopodobniej, „Za Wilno”.

115 Zob.: Dziennik Rozkazów MSWojsk. nr 49 z 13 XII 1921 r., poz. 872 - załącznik 2; 
Zapewne wymienione w niniejszym opracowaniu odznaki i oznaki nie wyczerpują całego katalogu przedmiotów tego typu zawierających w sobie jakieś elementy symboliczne związane $\mathrm{z}$ etosem byłego Wielkiego Księstwa Litewskiego. Wydaje się jednak, że wskazano na najistotniejsze $\mathrm{z}$ nich.

Z przytoczonych powyżej faktów wynika, że najczęściej występującym na weksyliach oraz na odznakach i oznakach Wojska Polskiego elementem nawiązującym do tradycji byłego Wielkiego Księstwa Litewskiego była Pogoń i wizerunek Matki Boskiej Ostrobramskiej. Jedynie incydentalnie pojawiały się też inne symbole odnoszące się do państwowości litewskiej, a mianowicie Słupy Giedymina. Często natomiast można było na nich znaleźć herby miast i ziem leżących na „litewsko-białoruskich” Kresach dawnej Rzeczypospolitej Obojga Narodów oraz Drugiej Rzeczypospolitej. Ponadto niemal wszystkie formacje kultywujące w latach 1918-1939 te tradycje należały do oddziałów, których historia była silnie związana najpierw z polską Samoobroną Litwy i Białorusi, a następnie z Dywizją Litewsko-Białoruską.

Pewne elementy etosu byłego Wielkiego Księstwa Litewskiego traktowanego jako integralna część dawnej Rzeczypospolitej Obojga Narodów znalazły się także $\mathrm{w}$ treściach pogadanek wykorzystywanych jako jedna z metod wychowawczych w polskich siłach zbrojnych. Duża liczba mniejszości narodowych, które po 1921 roku zamieszkiwały terytorium Rzeczypospolitej Polskiej i siłą rzeczy były wcielane w szeregi Wojska Polskiego ${ }^{116}$, powodowała, że w działaniach mających wychować żołnierza-obywatela, obok miłości ojczyzny, starano się też rozwijać przywiązanie do własnego państwa i jego przeszłości. W wyniku tego zarówno w pierwszej połowie

W. Bigoszewska, A. Jońca - rysunki, Polskie ordery i odznaczenia, Warszawa 1989, s. 69; M. Wełna, Wojsko Polskie i Samoobrona w obronie ziem polskich na wschodzie w latach 1918-1920. Odznaki pamiqtkowe i okolicznościowe, Wrocław 2001, s. 96-103, 116, 122, 183-190. Ponadto zob. także: Z. Puchalski, Odznaczenia i odznaki z okresu walk o granice państwa 1918-1921, „Zeszyt Naukowy Muzeum Wojska”, 1991, z. 5; S. Oberleitner, Polskie ordery, odznaczenia i niektóre wyróżnienia zaszczytne 1705-1990. Vademecum dla kolekcjonerów, t. 1: Ordery, odznaczenia i odznaki 1705-1831; 1918-1939; 1940-1989, Zielona Góra 1992; W. Stela, Polskie odznaki honorowe i pamiatkowe 1914-1918 \& 1918-1921 (wojny o granice państwa), Warszawa 2001.

116 Szerzej na ten temat, obok części wcześniej cytowanej literatury, zob. także: J. Odziemkowski, Wieś i armia w II Rzeczypospolitej, Wrocław-Warszawa-Kraków-Gdańsk-Łódź 1988; J. Grzybowski, Białorusini w polskich regularnych formacjach wojskowych w latach 1918-1945, Warszawa 2006. 
lat 20., jak i po przewrocie majowym większy nacisk kładziono jednak na budowanie więzi państwowych niż narodowych. W warunkach państwa zamieszkanego przez blisko $1 / 3$ obywateli obcego pochodzenia propagowanie przez wojsko idei solidaryzmu państwowego należy uznać za rozsądne rozwiązanie ${ }^{117}$.

Pogadanki historyczne były jedną z podstawowych form wychowania patriotycznego i obywatelskiego. Tematyka „polsko-litewska” pojawiła się w ich treści już latem 1919 roku przy okazji obchodów 350. rocznicy unii lubelskiej ${ }^{118}$. Jednak historia niejednokrotnie była wykorzystywana jako swego rodzaju tworzywo do konstruowania zajęć odnoszących się do problematyki współczesnej. Stąd też była traktowana bardzo wybiórczo, przede wszystkim jako instrument kształtowania pożądanych postaw. Temu samemu celowi służył dobór odpowiednich zagadnień przeznaczonych do omówienia. Nie zawsze dbano także o zgodność prezentowanych w pogadankach treści z ogólnie przyjętymi ustaleniami nauki historycznej. Stąd też żołnierz Wojska Polskiego mógł na przykład dowiedzieć się, że pierwsza unia polsko-litewska została zawarta nie w 1385 roku w Krewie, lecz w Horodle, i to na dodatek dopiero po bitwie pod Grunwaldem ${ }^{119}$.

Należy jednak zauważyć, że kwestie związane z istnieniem w ramach jednej Rzeczypospolitej Obojga Narodów, obok Korony, również Wielkiego Księstwa Litewskiego nie były zbyt częstym tematem wspomnianych pogadanek. Ponadto problematyka ta była przedstawiana w bardzo zubożonej, a niekiedy nawet dość enigmatycznej formie. W jednej z oficjalnych instrukcji, która ukazała się drukiem już w 1920 roku, zalecano, aby: „Świetności i rozrostowi państwa polskiego doby jagiellońskiej przeciwstawiać dalszy upadek wieku XIX-go i wskrzeszenie wieku XX-go" ${ }^{120}$. W dalszej części tego dokumentu radzono, jak wykorzystywać i in-

117 Szerzej na ten temat zob. J. Kęsik, op. cit., s. 143 i passim.

${ }_{118}$ W rozkazie dowództwa Frontu Galicyjsko-Wołyńskiego zarządzono: „Referenci oświatowi przygotują i urządzą w miesiącu lipcu br. we wszystkich oddziałach uroczyste obchody 350-letniej rocznicy Unii Polski z Litwą, a przede wszystkim w formie odpowiednio przygotowanych odczytów lub wykładów zaznajomią żołnierzy ze znaczeniem tej uroczystości. Wzorowe [tutaj w sensie wzorcowe - przyp. A. S.] odczyty względnie broszury, mogące służyć za podstawę do prelekcji, są przygotowane w Uniwersytecie Żołnierskim [...], które wysyła się na żądanie" - zob. CAW, Generalny Inspektorat Artylerii, sygn. 300.26.14, Rozkaz nr 112 Kwatermistrzostwa Dowództwa Frontu Galicyjsko-Wołyńskiego z 5 VII 1919 r.

119 J. Kęsik, op. cit., s. 147; J. Odziemkowski, Armia i społeczeństwo II Rzeczypospolitej, s. 52.

${ }^{120}$ K. Sochaniewicz, op. cit., s. 19. 
terpretować dzieła polskiego malarstwa historycznego: „Weźmy np. Bitwę pod Grunwaldem. Podmalowanie tła dziejowego (przezrocza Władysława Jagiełly, Witolda i innych postaci), Unia polsko-litewska (epizod o związkach narodów), obraz bitwy [...], rola solidarności Polaków i Litwinów (solidarność obywatelska w ogólności)"'121.

W jednej z propozycji dotyczącej metod wychowawczych stosowanych w wojsku, opracowanej na początku lat 30 . i zawierającej wykaz zalecanych tematów pogadanek historycznych, przy temacie zatytułowanym „Kto to była Jadwiga i czym zapisała się w historii”, napisano: „Jadwiga była córką króla węgierskiego Ludwika. [...] Dzięki małżeństwu jej z księciem litewskim Władysławem Jagiełłą następuje połączenie Polski i Litwy - początkowo przez wspólną osobę króla - a z czasem oba te kraje złączyły się ze sobą i stanowiły jedno wielkie państwo: Polskę. W tym też czasie przeszli Litwini na wiarę chrześcijańską"122.

Przy omawianiu tematu „Co wiecie o roku 1410?” należało przekazać słuchaczom: „Dnia 15 lipca 1410 r. zetknęli się Krzyżacy z wojskami polsko-litewskimi i pod Grunwaldem stoczono bitwę. W bitwie tej rycerstwo polskie i Litwini rozgromili zupełnie Krzyżaków"123.

W nieco późniejszej i jednocześnie uzupełnionej wersji tych propozycji tematycznych znalazło się również zagadnienie „Kto to był hetman Chodkiewicz?". Napisano tam:

Chodkiewicz był hetmanem litewskim, który odniósł świetne zwycięstwo nad Szwedami pod Kircholmem [...]. Następnie po zwycięstwie Turków pod Cecorą i wyruszeniu tych na podbój Polski z 300000 ludzi, stanął hetman Chodkiewicz na czele rycerstwa polskiego i Kozaków ${ }^{124}$, aby wspólnie bronić za-

121 Ibidem, s. 33.

${ }_{122}$ Zbiór pytań i odpowiedzi, s. 313-314. Zob. także: E. Jasiński, M. Słowikowski, op. cit., s. 363. Podobne treści znalazły się też w dziale Wiadomości o Polsce. Historia zamieszczonym w Podręczniku przysposobienia wojskowego, Warszawa [b.r.w.], s. 3, gdzie napisano: „Po Ludwiku na tronie polskim zasiadła córka jego Jadwiga [...]. Dzięki małżeństwu z księciem Litwy Władysławem Jagiełła, następuje połączenie Polski i Litwy - naprzód przez wspólną osobę króla - a z czasem oba kraje złączyły się zupełnie ze sobą i stanowiły jedno wielkie państwo - Rzeczpospolitą Polską. Połączenie ich było koniecznością dziejową, gdyż Krzyżacy [...] zaczęli coraz bardziej zagrażać Litwie i Polsce. Jako pierwszy widomy skutek połączenia Polski i Litwy było wielkie zwycięstwo nad Krzyżakami pod Grunwaldem w 1410 r."

${ }^{123}$ Zbiór pytań i odpowiedzi, s. 314. Zob. także E. Jasiński, M. Słowikowski, op. cit., s. 363.

${ }^{124}$ O Litwinach nie ma tam ani słowa, a także oni byli przecież wtenczas pod Chocimiem 
grożonej Ojczyzny. Pod Chocimiem stanął Chodkiewicz warownym obozem [...]. Sułtan turecki przekonał się po kilku nieudanych szturmach, że obozu nie zdobędzie i [...] poprosił o rozejm. Polacy na rozejm ten chętnie przystali, gdyż umarł tymczasem, skutkiem trudów życia obozowego, hetman Chodkiewicz [...]. Zwycięska walka pod Chocimiem rozsławiła szeroko i daleko imię Polski jako przedmurza chrześcijaństwa ${ }^{125}$.

Pogadanki te prezentowały więc niezwykle uproszczoną wizję dziejów Rzeczypospolitej Obojga Narodów, wizję, w której niemal wszystkie osiągnięcia były udziałem Polaków, a rola Litwinów ginęła w mrokach historii. Stąd też żołnierz Wojska Polskiego miał małe szanse, aby dowiedzieć się choćby tego, że Tadeusz Kościuszko z pochodzenia był Litwinem, a nie Polakiem ${ }^{126}$ - oczywiście w dwudziestowiecznym znaczeniu tego słowa.

Innym przykładem szczególnie instrumentalnego traktowania przeszłości wspólnego polsko-litewskiego państwa było zalecenie, które znalazło się we wzorcowym zestawie pogadanek historycznych na rok 1938. Otóż przy temacie dotyczącym wydarzeń związanych z bitwą grunwaldzką z 15 lipca 1410 roku, jako naukę dla żołnierzy, polecano następujące zdanie: „Bez Polski Litwa jest małym, słabym państwem” 127 .

Już choćby z tego, z konieczności bardzo pobieżnego, przeglądu treści dydaktycznych związanych z etosem byłej Rzeczypospolitej Obojga Narodów oraz Wielkiego Księstwa Litewskiego widać, że odpowiednio „przekształcona” wizja ich dziejów miała przede wszystkim służyć budowie dumy narodowej u żołnierzy pochodzenia polskiego oraz dumy państwowej u reszty szeregowych. Natomiast zapoznanie ich z prawdziwą i rzetelnie podaną historią nie miało tutaj większego znaczenia ${ }^{128}$. Wła-

-zob. choćby: J. Tretiak, Historia wojny chocimskiej (1621), Kraków 1921; L. Podhorodecki, Chocim 1621, Warszawa 1988.

125 E. Jasiński, M. Słowikowski, op. cit., s. 365-366.

126 Ibidem, s. 369-370.

127 J. Odziemkowski, Armia i społeczeństwo II Rzeczypospolitej, s. 52.

128 Problematyka ta, choćby z racji jej złożoności oraz różnych instytucji zajmujących się pracą wychowawczą i działalnością dydaktyczną w Wojsku Polskim Drugiej Rzeczypospolitej, wymaga jednak dalszych pogłębionych badań źródłowych. Dotychczasowa historiografia polska nie daje bowiem odpowiedzi na cały szereg stawianych tutaj pytań i zagadnień badawczych - oprócz części wcześniej cytowanej literatury zob. chociażby: E. J. Kryńska, Polski Biały Krzyż (1918-1961), Białystok 1997; L. Wyszczelski, Oświata, propaganda, kultura w Wojsku Polskim w latach 1918-1945, Warszawa 2004; A. Niewęgłowska, Polski Biały Krzyż a wojsko (1919-1939), Toruń 2005. 
dzom wojskowym chodziło przecież o zupełnie co innego, a mianowicie o ukształtowanie świadomego i odpowiedzialnego za państwo obywatela-żołnierza ${ }^{129}$.

Wydaje się więc, że dla zachowania wśród oficerów służby stałej i podoficerów zawodowych Wojska Polskiego, a także wśród poborowych narodowości polskiej, głównie tych pochodzących z terenów etnicznie polskich oraz z Kresów Północno-Wschodnich, świadomości etosu ziem stanowiących niegdyś obszar Wielkiego Księstwa Litewskiego, a po 1922 roku należących do państwa polskiego, większe znaczenie miały opisane wcześniej weksylia oraz przedmioty falerystyczne niż podejmowane w siłach zbrojnych w latach 1920-1939 działania wychowawcze, edukacyjne i propagandowe. Te pierwsze były bowiem widomym symbolem łączności służących w poszczególnych pułkach żołnierzy z ziemiami i miejscowościami, o które oddziały te walczyły w czasie „wojen o niepodległość i granice", a więc w latach 1918-1921. Ich wartość podnosi również fakt, że ich istnienie w Wojsku Polskim nie było wynikiem żadnych odgórnych rozkazów i nakazów, lecz efektem wewnętrznej potrzeby kadry oficerskiej i podoficerskiej wymienionych powyżej pułków oraz polskich mieszkańców ówczesnych Kresów Północno-Wschodnich.

Możliwość pełnego wykorzystania przez Wojsko Polskie tradycji ziem byłego Wielkiego Księstwa Litewskiego komplikował jednak fakt istnienia niepodległego państwa litewskiego, z którym na dodatek Rzeczpospolita Polska niemal przez cały okres międzywojenny była w złych, a nawet bardzo złych stosunkach politycznych i wojskowych ${ }^{130}$.

129 Szerzej na ten temat oraz kwestii ocen osiaganych wtenczas efektów zob. choćby J. Kęsik, op. cit., s. 154-155.

${ }^{130}$ Szerzej na ten temat, oprócz części wcześniej cytowanej literatury, zob. także: P. Stawecki, Polityka wojskowa Polski 1921-1926, Warszawa 1981; M. Leczyk, Polska i sqsiedzi. Stosunki wojskowe 1921-1939, Warszawa 2004. 


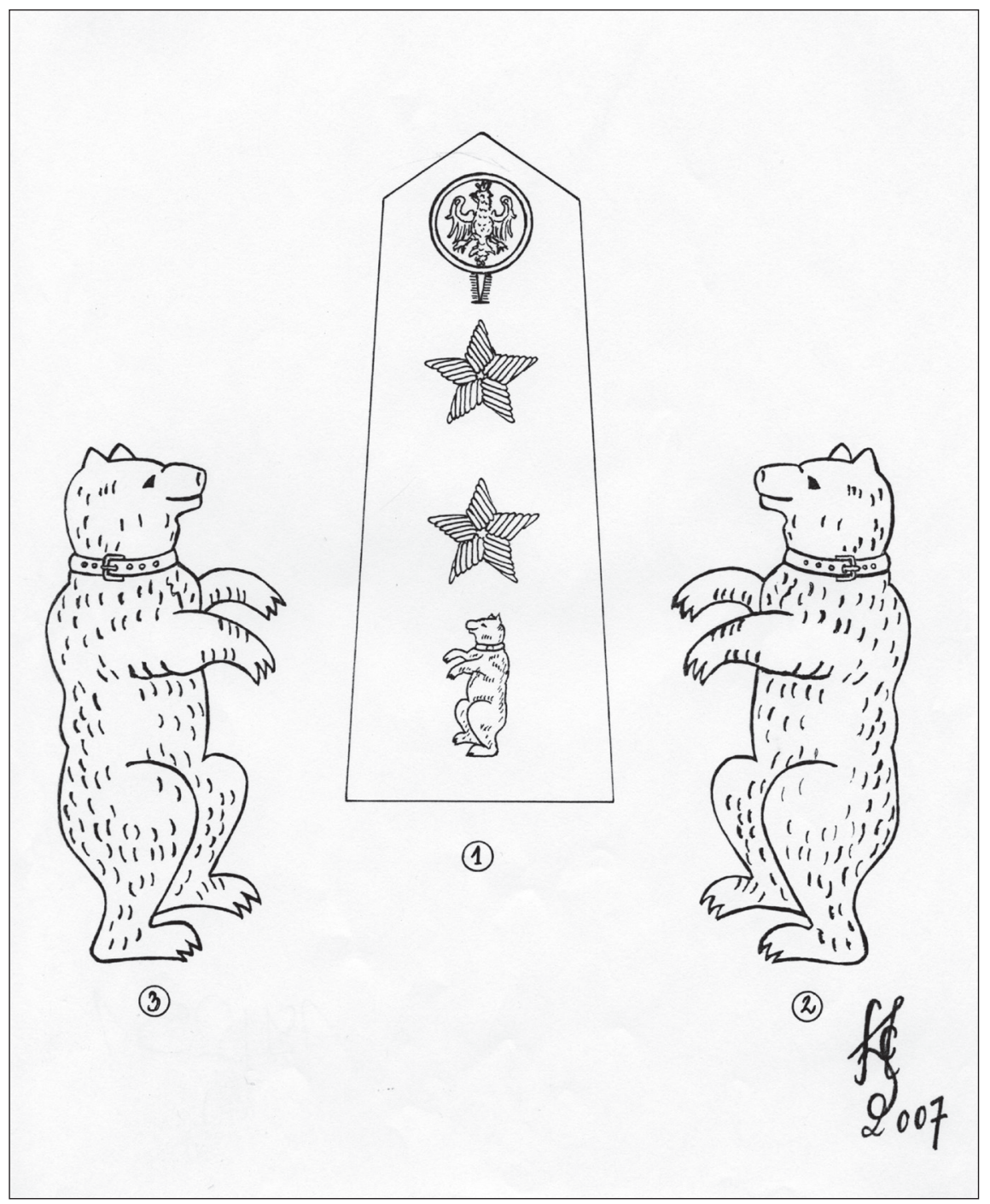

Tablica 1. Oznaki naramienne „Niedźwiedź” noszone na naramiennikach kurtek i płaszczy w 77. Pułku Strzelców Kowieńskich (rys. A. Smolińska):

1) Przepisowy wygląd naramiennika porucznika z oznaką „Niedźwiedzia”,

2) Przepisowy wygląd heraldycznej oznaki „Niedźwiedzia”,

3) Wygląd nieheraldycznej oznaki „Niedźwiedzia”

Źródło: Dziennik Rozkazów MSWojsk. nr 34 z 22 VIII 1922 r., poz. 493; W. Markert, 77 Putk Strzelców Kowieńskich w latach 1918-1939, Pruszków 2003, s. 82. 


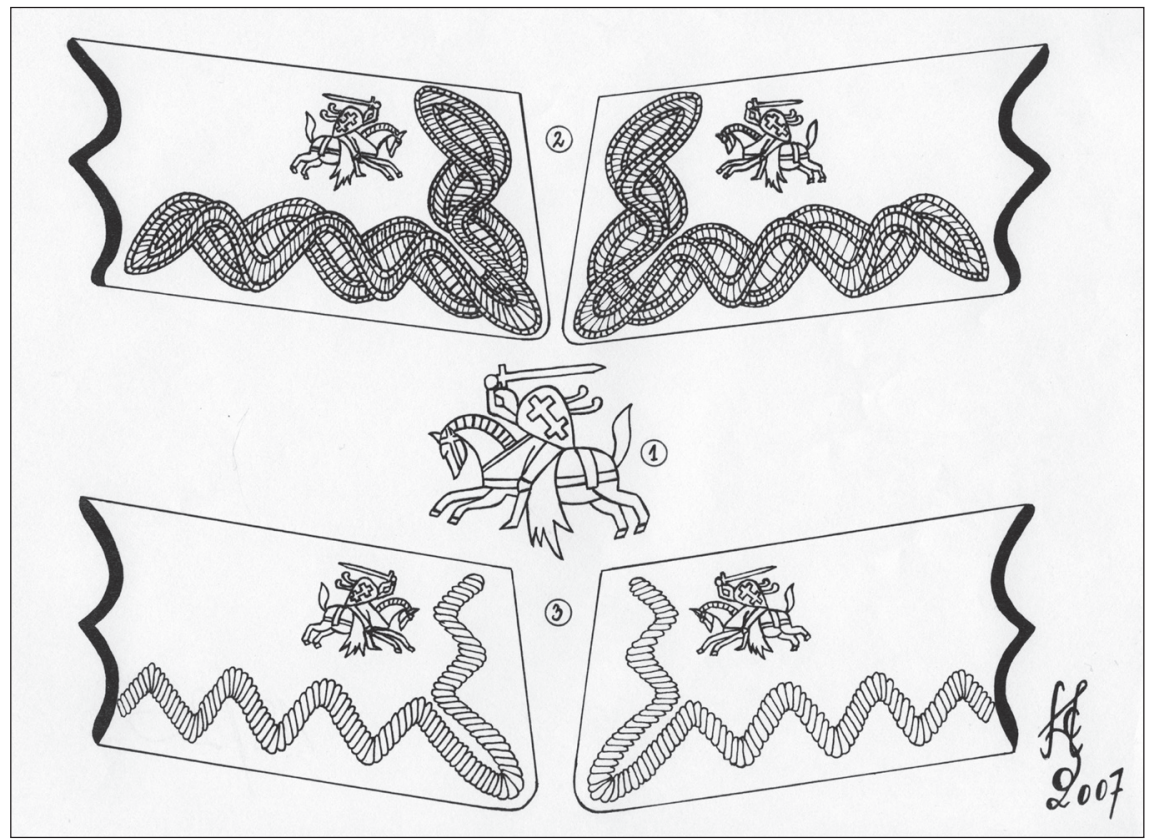

Tablica 2. Przepisowy wygląd oraz sposób noszenia oznak „Pogoń” na kołnierzach kurtek w 85. Pułku Strzelców Wileńskich (rys. A. Smolińska):

1) Przepisowy wygląd metalowej oznaki „Pogoń” przeznaczonej do noszenia na kołnierzach kurtek,

2) Przepisowy sposób umieszczania oznak „Pogoni” na kołnierzach kurtek oficerów i chorążych,

3) Przepisowy sposób umieszczania oznak „Pogoni” na kołnierzach kurtek pozasłużbowych podoficerów zawodowych i nadterminowych

Źródło: Dziennik Rozkazów MSWojsk. nr 9 z 15 III 1927 r., poz. 73; ibidem, nr 22 z 4 VIII 1927 r., poz. 268; oraz ibidem, nr 24 z 30 VII 1930 r., poz. 286. 


\section{Traditions of Grand Duchy of Lithuania in Polish infantry 1918-1939 (summary)}

Traditions are very important element of mass conciousness, which should characterize both society and army. Until recently on the European continent military traditions were one of important and carefully cultivated. One of the elements in the multithreaded traditions functioning in Polish armed forces before 1939, was the ethos of former Polish-Lithuanian Commonwealth and thus the memory of the relationship between the Crown and Grand Duchy of Lithuania. As well, building the consciousness of those traditions in the military was convergent with the official policy of Polish political elites.

One of the ways in which in the years 1921-1939 the Polish armed forces operated in the ethos of the former Polish-Lithuanian Commonwealth. In addition to native Polish, and military traditions of the lands forming part of the former Grand Duchy of Lithuania were cultivated. In the course of training some conscripts from this lands an educational content recommended by the chief military authorities was used. Important components of this tradition were the bosses and the names and branches of the Polish Army and elements of symbolism and even departmental banners or commemorative badges.

Therefore, the author tried to present the history of all infantry formations of the Polish Army in the years 1918-1939, which were cultivating ethos of the former Grand Duchy of Lithuania. As well described how these facts were externalized in symbolic representation of those formations: banners, own names and commemorative badges. In addition, author gives information how these facts were used in the process of training and education of soldiers serving in these regiments. 
(cC) $(9)$ 